\title{
Lifting the Curse of the SOX Through Employee Assessments of the Internal Control Environment
}

Thuy-Nga T. Vo ${ }^{*}$

\section{INTRODUCTION}

In 1919, eight Chicago White Sox baseball players allegedly participated in a scheme to intentionally lose games during the World Series. ${ }^{1}$ For this misdeed, some say the White Sox were subjected to a curse whereby the team was unable to win a World Series title for eighty-six years. ${ }^{2}$ The scandal so tainted the White Sox that their affliction became known as the curse of the "Black Sox." 3 Not until 2005 was the team able to lift the curse of the Black Sox by winning the World Series title over the Houston Astros. ${ }^{4}$

In 1920, the Boston Red Sox baseball team's owner sold Babe Ruth to the New York Yankees. ${ }^{5}$ This sale, some say, was such a controversial move that it subjected the Red Sox to their own curse whereby the team was unable to win a World Series title. ${ }^{6}$ The curse was dubbed "the curse of the Bambino" after the nickname of the baseball legend involved in the sale. ${ }^{7}$ Eighty-four years after the sale, the curse of

* Associate Professor of Law, William Mitchell College of Law; J.D., Harvard Law School; B.A., summa cum laude, University of Minnesota. In the interest of full disclosure, I note that I was formerly the Director of Finance and a member of the SOX Compliance Committee of a Fortune 500 company. I am grateful for the helpful comments on this article offered by Professor Donald Langevoort of Georgetown University Law Center, as well as by my colleagues Daniel Kleinberger, Kenneth Port, Niels Schaumann, and Deborah Schmedemann. I thank Michael A. Duffy, Esq., for his insights and support.

1. See generally Eliot Asinof, Eight Men Out (Henry Holt \& Co. 1987) (1963) (presenting "a reconstruction of the Black Sox scandal").

2. See David Thigpen, Every Year, a Miracle, Time, Oct. 31, 2005, at 75 (blaming Chicago baseball teams' failure to win a World Series in eighty-eight years in part on the "'Black Sox' (the team that threw the 1919 Series)").

3. See id. (comparing Chicago's streak without a title to that of the "Boston Red Sox, whose curse-crushing triumph [in 2004] proved that nobody can lose forever").

4. See Editorial, An 88-Year Wait, Ended, WASH. Times, Oct. 28, 2005, at A12.

5. Dan Shaughnessy, Reversing the Curse: Inside the 2004 Boston Red Sox 2, 23 (2005).

6. See id. at 2-3.

7. See id. at 2,8-10. 
the Bambino was finally lifted when the Red Sox defeated the St. Louis Cardinals in the 2004 World Series. ${ }^{8}$

The curse of the "SOX" (the business world's acronym for the Sarbanes-Oxley Act of 2002) $)^{9}$ also arose out of scandals and controversy. The curse began when Congress passed SOX in response to wellpublicized corporate failures and accounting fraud at Enron, WorldCom, Tyco, and other large public companies. ${ }^{10}$ As this Article will discuss, the curse of SOX has subjected public companies to a host of legislative and regulatory requirements and caused public companies to incur unanticipated opportunity and monetary costs.

The most challenging provision of SOX has been section 404 ("SOX 404 "), ${ }^{11}$ which requires public companies to establish and conduct an assessment of their internal controls over financial reporting ("ICFR"). ${ }^{12}$ In addition to requiring senior management to report on the effectiveness of ICFR, SOX 404 mandates that public companies obtain external auditor attestations to senior management's assessments. ${ }^{13}$ Although the legislation was enacted in 2002, application of SOX 404 has been delayed repeatedly for nearly half of all domestic public companies due to the outcry over the lack of implementation guidance and the substantial compliance costs. ${ }^{14}$

This Article posits that the opportunity and monetary costs imposed on the corporate world by the curse of SOX can be lifted in much less time than it took to lift the curses that plagued the Red Sox and White Sox, and that the goals behind the legislation can be more effectively achieved. Instead of implementing SOX 404 by requiring management to conduct an assessment of the company's internal accounting controls, SOX 404 should be implemented by requiring the company to conduct an assessment of its internal control environment. Assessment of the internal control environment can be achieved by having employees assess and report on senior management's behavior and ethics. Employee assessments of management's behavior and ethics will be

8. Id. at $1-2$.

9. Pub. L. No. 107-204, 116 Stat. 745 (codified in scattered sections of 11, 15, 18, 28, and 29 U.S.C.).

10. E.g., ERic A. Chiappinelli, Cases AND Materials on Business Entities 17 (2006); Robert W. HAMilton \& JONATHAN R. MACEy, CASES AND Materials ON CORPORATIONS INCLUDING PARTNERSHIPS AND LIMITED LIABILITY COMPANIES 589-90 (9th ed. 2005); ARTHUR R. PinTO \& DOUgLaS M. BRANSON, UNDERSTANDING CORPORATE LAW 130 (2d ed. 2004).

11. Sarbanes-Oxley Act of $2002 \S 404,15$ U.S.C. $\S 7262$ (Supp. IV 2004).

12. 15 U.S.C. $\$ 7262(a)$

13. Id. $\S 7262(\mathrm{~b})$.

14. See infra Parts II.C., III.A. 
more effective in improving financial reporting quality and corporate integrity than the management assessments of internal accounting controls currently interpreted to be required under SOX 404.

Part II of this Article examines the legislative and regulatory background of SOX 404, including the internal control systems required under this statutory provision and the ensuing regulatory guidance to public companies to comply therewith. Part III examines the resulting opportunity and monetary costs of compliance, and reveals that these costs are high and have resulted from lack of regulatory guidance and public companies' misdirected focus on the minutiae of internal accounting controls instead of the overall internal control environment. Part IV determines that implementation of SOX 404 and regulatory guidance missed the goals of improving financial accuracy and corporate integrity, because reform efforts focusing on internal control activities are ineffective at assessing and improving corporate behavior. Part $\mathrm{V}$ proposes a new method of assessing and improving organizational integrity - employee assessments of management ethics.

This Article concludes that an employee assessment and reporting of senior management's behavior and ethics is a cheaper and more effective method of detecting financial reporting fraud and improving corporate behavior than the current implementation of SOX 404's requirement of a management assessment and reporting of ICFR. By requiring public companies to conduct and report employee assessments of executive behavior and ethics, the curse of SOX can be lifted. Because this form of assessment and reporting is a less costly and more effective method of determining organizational integrity and financial reporting accuracy, it can lift the curse of SOX in much less time than it took to lift the curses of the Red Sox and White Sox.

\section{LEGISLATIVE AND REGULATORY FRAMEWORK}

The Public Company Accounting Reform \& Investor Protection Act of 2002, better known as the Sarbanes-Oxley Act of 2002, ${ }^{15}$ was enacted in reaction to well-publicized corporate failures and allegations of fraud in financial reporting. The overarching purpose of SOX was to restore investor confidence by improving the integrity of financial reporting. ${ }^{16}$

15. Pub. L. No. 107-204, 116 Stat. 745 (codified in scattered sections of 11, 15, 18, 28, and 29 U.S.C.).

16. Final Rule: Management's Reports on Internal Control over Financial Reporting and Certification of Disclosure in Exchange Act Periodic Reports, Securities Act Release No. 8238, Exchange Act Release No. 47,986, Investment Company Act Release No. 26,068, 68 Fed. Reg. 
SOX applies to public companies, which include any company whose stock is publicly traded on an exchange and most companies whose stock is traded on the over-the-counter or pink sheet market, any company that has filed a registration statement to issue securities in the future, and any other entity that is required to file annual and quarterly reports. ${ }^{17}$

\section{A. Section 404 Requirements}

One of the most challenging requirements of SOX involves a company's responsibility to implement internal controls. As discussed below, public companies have been required to establish and maintain a system of internal controls since passage of the Foreign Corrupt Practices Act of $1977,{ }^{18}$ and the concept of internal controls has been well defined by the accounting and auditing professions prior to the enactment of SOX. ${ }^{19}$ By expanding upon the longstanding requirements that public companies establish and maintain effective internal controls over financial reporting, Congress expected SOX 404 would result in more accurate financial statements and consequently restore investor confidence in the U.S. capital markets. ${ }^{20}$ Particularly noteworthy and controversial, SOX 404 goes beyond requiring companies to establish and maintain ICFR by requiring management to assess and report on the effectiveness of the company's ICFR. ${ }^{21}$ In addition, SOX 404 requires the company's external auditors, after management's assessment has been completed, to provide an attestation and a report on the assessment made by the company's management. ${ }^{22}$ These requirements imposed by SOX 404 have proven more onerous than anticipated, and corporations across the United States have felt the painful impact. ${ }^{23}$

36,636, 36,656 (June 18, 2003) [hereinafter Final Rule on Internal Control]; Leonard M. Baynes, Just Pucker and Blow?: An Analysis of Corporate Whistleblowers, the Duty of Care, the Duty of Loyalty, and the Sarbanes-Oxley Act, 76 ST. JOHN'S L. REV. 875, 890 (2002) (explaining that SOX was designed to promote investor confidence by requiring disclosures of information about possible corporate fraud so investors could make informed investment decisions).

17. See Sarbanes-Oxley Act of 2002 § 2(a)(7), 15 U.S.C. § 7201(7) (Supp. IV 2004) (defining "issuer" for purposes of the Act).

18. Pub. L. No. 95-213, 91 Stat. 1494 (codified as amended in scattered sections of 15 U.S.C.).

19. See infra note 39 and accompanying text.

20. See Office of The Chief Accountant, Div. of Corp. Fin., U.S. Sec. \& Exch. Comm'N, MANAGEMENT'S REPORT ON INTERNAL CONTROL OVER FINANCIAL REPORTING AND Certification of Disclosure in Exchange ACt Periodic Reports: Frequently Asked QUESTIONS (2004), http://www.sec.gov/info/accountants/controlfaq1004.htm.

21. 15 U.S.C. $\$ 7262(\mathrm{a})(2)$.

22. Id. § 7262(b).

23. See Stephen Wagner \& Lee Dittmar, The Unexpected Benefits of Sarbanes-Oxley, HaRV. Bus. REV., Apr. 2006, at 133, 133 (discussing the compliance burdens of SOX 404 versus the provision's benefits in improving financial management processes); Mark W. Olson, Chairman, Pub. 
The rules promulgated by the Securities and Exchange Commission (the "Commission") to implement SOX 404 provide that management's internal control report must be incorporated into the annual report and must include the following components: management's recognition of its responsibility for establishing and maintaining adequate internal controls and procedures for financial reporting, the framework used by management in its evaluation of ICFR, management's assessment of the effectiveness of the company's ICFR as of the end of the company's most recent fiscal year, the disclosure of any material weaknesses in the company's ICFR identified by management, and a statement indicating that the external auditors have issued an attestation report on management's assessment of the effectiveness of the company's ICFR. ${ }^{24}$ Public Company Accounting Oversight Board Auditing Standard No. 2, which covers the auditor's attestation to management's assessment of the company's ICFR, is the standard that auditors must use to satisfy their obligations under SOX 404. ${ }^{25}$ An external attestation of the company's ICFR requires the auditor to obtain an understanding of the company's internal control system, test and evaluate the design and operating effectiveness of the company's internal controls, and opine on management's assessment of the company's internal controls. ${ }^{26}$

The Commission requires any public company meeting the definition of "accelerated filer" under Rule $12 \mathrm{~b}-2^{27}$ of the Securities Exchange Act of $1934^{28}$ (i.e., a company with equity market capitalization over $\$ 75$ million and at least one annual report filing with the Commission) to report annually on the company's ICFR for fiscal years ended on or after November 15, 2004 (amounting to a delay of five months from the originally proposed compliance date of June 15, 2004 and fifteen months from the original effective date of August 14, 2003). ${ }^{29}$ Public companies

Co. Accounting Oversight Bd., Auditor Oversight, Corporate Boards and the Benefit for Our Capital Markets, Speech at the National Association of Corporate Directors Annual Corporate Governance Conference: Driving Long-Term Value (Oct. 17, 2006), available at http://www.pcaobus.org/ News_and_Events/Events/2006/Speech/10-17_Olson.aspx (expressing that addressing the costs of implementing SOX 404 has been on the top of the agendas of Congress, Wall Street, and boardrooms in the United States and abroad).

24. Final Rule on Internal Control, supra note 16, at 36,642.

25. See Public Company Accounting Oversight Board; Order Approving Proposed Auditing Standard No. 2, Exchange Act Release No. 49,884, 69 Fed. Reg. 35,083, 35,083-84 (June 23, 2004).

26. Id. at 35,084 .

27. 17 C.F.R. $\S 240.12 b-2(2006)$.

28. 15 U.S.C. $\S \S 78 \mathrm{a}-78 \mathrm{nn}(2000$ \& Supp. IV 2004).

29. Management's Report on Internal Control over Financial Reporting and Certification of Disclosure in Exchange Act Periodic Reports, Securities Act Release No. 8392, Exchange Act Release No. 49,313, Investment Company Act Release No. 26,357, 69 Fed. Reg. 9722, 9722-23 (Mar. 1, 2004). 
that are not "accelerated filers" are required to comply with the management assessment requirements for fiscal years ended on or after December 15, 2007, and with the auditor attestation requirements for fiscal years ended on or after December 15, 2008 (amounting to a delay of almost four years from the original compliance date of April 15, 2005). ${ }^{30}$ The Commission estimates that approximately six thousand companies, or sixty percent of all registered public companies, were nonaccelerated filers as of $2005 .^{31}$ Thus, more than half of all public companies are not yet subject to the requirements of SOX 404. The continual delays in implementation of SOX 404 have been caused by corporate outcry over the amount of opportunity and monetary costs that companies have incurred in their attempt to comply with the ICFR requirements. ${ }^{32}$

Public companies' vociferous concerns and questions about SOX 404 , in addition to prompting the Commission to delay the compliance date for non-accelerated filers, have also led the Commission to establish an advisory committee ${ }^{33}$ to assist the Commission in evaluating the current regulations on disclosure, financial reporting, and internal controls of public companies. ${ }^{34}$ In its final report to the Commission, the advisory committee recommended the Commission exempt certain public companies with market capitalization of less than $\$ 128$ million from both the management assessment and auditor attestation requirements, and exempt certain public companies with market capitalization between $\$ 128$ million and $\$ 787$ million from the auditor attestation requirement. ${ }^{35}$ The advisory committee suggested that the proposed exemption of the management assessment and auditor attestation requirements, which would cover nearly eighty percent of all

30. Internal Control over Financial Reporting in Exchange Act Periodic Reports of NonAccelerated Filers and Newly Public Companies, Securities Act Release No. 8760, Exchange Act Release No. 54,942, 71 Fed. Reg. 76,580, 76,581-83 (Dec. 21, 2006).

31. See U.S. Gov'T ACCOUntability Office, GAO-06-361, SARbanes-OxLey ACt: CONSIDERATION OF KeY PRINCIPLES NEEDED IN AdDRESSING IMPLEMENTATION FOR SMALleR PUBLIC COMPANIES 10 (2006) [hereinafter GAO CONSIDERATION] (analyzing the compliance costs of SOX).

32. See discussion infra Part III.A.

33. See Advisory Committee on Smaller Public Companies, Securities Act Release No. 8514, Exchange Act Release No. 50,864, 69 Fed. Reg. 76,498, 76,498 (Dec. 21, 2004).

34. See Final Report of the Advisory Committee on SMaller Public Companies to THE United States SECURITIES AND EXChANGE COMMission 1-5 (2006), available at http:// www.sec.gov/info/smallbus/acspc/acspc-finalreport.pdf [hereinafter ADVISORY COMMITTEE REPORT] (defining "smaller public companies" as public companies with equity market capitalization of approximately $\$ 787$ million and less, which companies constitute $78.5 \%$ of all U.S. public companies and comprise $6 \%$ of total U.S. equity market capitalization).

35. See id. at 6-7. 
domestic public companies, be in effect until the Commission issues adequate guidance to assist in management's performance of an assessment of ICFR. ${ }^{36}$ The Commission has rejected the advisory committee's advice for exemption, stating instead that SOX 404 will ultimately apply to all public companies. ${ }^{37}$

\section{B. Internal Controls over Financial Reporting}

Rule 13a-15(c) under the Securities Exchange Act requires an assessment of a company's ICFR be based on a "suitable, recognized control framework that is established by a body or group that has followed due-process procedures, including the broad distribution of the framework for public comment." 38 The Committee of Sponsoring Organizations of the Treadway Commission ("COSO") 39 has developed a definition of internal control that is widely accepted in the accounting and auditing professions. COSO defines internal control as "a process, effected by an entity's board of directors, management and other personnel, designed to provide reasonable assurance regarding the achievement of objectives" in the categories of effectiveness and efficiency of operations, reliability of financial reporting, and compliance with applicable laws and regulations. ${ }^{40}$ COSO's definition has become the most widely used framework for establishing internal control structures at public companies. ${ }^{41}$

In its rules to implement SOX 404, the Commission amended its definition of ICFR to align it with the definition developed by COSO. ${ }^{42}$ Thus, Rule 13a-15(f) under the Securities Exchange Act now defines ICFR as a process to provide "reasonable assurance regarding the reliability of financial reporting and the preparation of financial

36. Id. at 6-7 \& n.13.

37. Steven Marcy, Companies Continue to Ask SEC for Leniency in Section 404 Guidance, 37 CORP. COUNS. WKLY. (BNA) 291, 291 (Sept. 27, 2006); Press Release, U.S. Sec. \& Exch. Comm'n, No. 2006-75, SEC Announces Next Steps for Sarbanes-Oxley Implementation (May 17, 2006), http://sec.gov/news/press/2006/2006-75.htm [hereinafter SEC Next Steps].

38. 17 C.F.R. § 240.13a-15(c) (2006).

39. See generally COOPERS \& LyBRAND, COMM. OF SPONSORING ORGS. OF THE TREADWAY COMM'N, INTERNAL CONTROL-INTEGRATED FRAMEWORK (1994) [hereinafter COSO INTEGRATED FRAMEWORK] (two-volume edition about internal control). COSO is a private sector organization sponsored by the American Institute of Certified Public Accountants, the American Accounting Association, the Institute of Internal Auditors, the Institute of Management Accountants, and the Financial Executives Institute. COSO Homepage, http://www.coso.org (last visited Sept. 18, 2007).

40. COSO InTEGRATED FRAMEWORK, supra note 39, Executive Summary, at 3.

41. Advisory Committee Report, supra note 34, at 26; Deloitte \& Touche, Audit COMMITTEE RESOURCE GUIDE 26-27 (2003).

42. See Final Rule on Internal Control, supra note 16, at 36,640-41. 
statements for external purposes," and such process includes policies and procedures that (1) "[p]ertain to the maintenance of records ... in reasonable detail [to] accurately and fairly reflect... transactions and dispositions of ... assets," (2) "[p]rovide reasonable assurance that transactions are recorded as necessary to permit preparation of financial statements in accordance with generally accepted accounting principles, and that receipts and expenditures" are properly authorized, and (3) "[p]rovide reasonable assurance regarding prevention or timely detection of unauthorized acquisition, use or disposition of . . . assets." 43 Because the focus of SOX 404 is on financial reporting, the Commission's definition of ICFR is not as broad as COSO's definition of ICFR. The Commission's definition does not encompass a company's operational effectiveness and efficiency or its "compliance with applicable laws and regulations, with the exception of compliance with the applicable laws and regulations directly related to the preparation of financial statements," such as the Commission's financial reporting requirements and the IRS tax code. ${ }^{44}$

The COSO framework of internal control is comprised of two substantive components. ${ }^{45}$ One component of the internal control system is the control environment, which for purposes of SOX means the overall attitudes, values, and philosophy of senior executives and the culture throughout the company relating to the timeliness and accuracy of financial reporting. ${ }^{46}$ Elements of the control environment include management's integrity, ethical values, professional competence, and operating style. ${ }^{47}$ The other component of the internal control system is control activities, which for purposes of SOX are comprised of policies, procedures, and systems relating to the reliability of financial reporting. ${ }^{48}$ Examples of control activities include policies regarding reconciling bank statements with checks issued, procedures governing the counting and valuation of inventory, and codes of conduct to guide employee

\footnotetext{
43. 17 C.F.R. $\S 240.13 a-15(f)$ (2006).

44. See Final Rule on Internal Control, supra note 16, at 36,640.

45. See COSO InTEgRATED FRAMEWORK, supra note 39, Executive Summary, at 4-5 (identifying three procedural or logistical components of the internal control system, including risk assessment, information communication, and monitoring). Risk assessment identifies the likelihood and impact of the risks faced by the company, information communication includes timely communication of relevant information throughout the organization in order for employees to perform their responsibilities, and monitoring determines whether the company's responses are effective against the identified risks. Id.

46. See id. at 4.

47. See id.

48. See id.
} 
behavior. Of these two components, the control environment is considered to be the "foundation" of the internal control system. ${ }^{49}$

\section{Lack of Legislative and Regulatory Guidance}

SOX 404 and its implementing regulations provide scant guidance regarding what is required of management in its assessment of ICFR. Former SEC Chairman Harvey Pitt has commented that SOX "was hastily - and, therefore, badly - drafted." ${ }^{50}$ In addition, large portions of SOX do not specify substantive rules but, instead, authorize the Commission to adopt implementing regulations. ${ }^{51}$ The Commission, in turn, has not provided definitive guidance with respect to the scope of management's assessment to satisfy the requirements of SOX 404. In adopting its implementation rules, the Commission expressly declined to specify the extent of management's assessment or the amount of documentation and testing that management must perform. ${ }^{52}$ Rather, the Commission simply stated that "[e]ach company is afforded the flexibility to design its internal control over financial reporting according to its own set of circumstances." $" 53$

During the first years of implementation, the Commission held two roundtable discussions and invited submissions from the public to solicit information and craft additional guidance for the implementation of SOX 404. ${ }^{54}$ The additional guidance, however, did not add much clarity to the implementation issues. For example, additional guidance from the Commission included "[it] is the responsibility of management to determine the form and level of controls appropriate for each organization and to scope their assessment and testing accordingly,, 55 and the "scope and process of the assessment should be reasonable, and

\footnotetext{
49. Id.

50. Harvey L. Pitt, Make SOX Fit, WALl St. J., Apr. 13, 2006, at A12.

51. See Sarbanes-Oxley Act of 2002, Pub. L. No. 107-204, 116 Stat. 745 (codified in scattered sections of 11, 15, 18, 28, and 29 U.S.C.).

52. Office of the Chief Accountant, Div. of Corp. Fin., U.S. SeC. \& EXch. Comm'N, StafF Statement on MANAGEMEnT's Report on Internal Control over Financial REPORTING 3 (2005), available at http://www.sec.gov/info/accountants/stafficreporting.pdf [hereinafter STAFF STATEMENT ON INTERNAL CONTROL].

53. Final Rule on Internal Control, supra note 16, at 36,659.

54. Concept Release Concerning Management's Reports on Internal Control over Financial Reporting, Exchange Act Release No. 54,122, 71 Fed. Reg. 40,866, 40,867-69 (July 18, 2006) [hereinafter Concept Release on Internal Control].

55. StAFF Statement On InTERnal CONTROL, supra note 52, at 2-3.
} 
the assessment (including testing) should be supported by a reasonable level of evidential matter." 56

After two years of implementation, the Commission continued to field protests over the high costs of SOX 404 compliance and the lack of clarity on the scope of assessment required of management. ${ }^{57}$ As the business community continued to seek additional guidance from regulators into the third year of compliance for accelerated filers, the Commission held additional roundtable discussions in 2006 to gather input from public companies, auditors, investors, lawyers, and educators on how to manage the costs and implementation details of SOX $404 .{ }^{58}$

\section{IMPLEMENTATION RESULTS AND CONSEQUENCES}

Reaction to SOX as a whole statute has been mixed. Supporters praise the strength of various provisions of the statute or the overall message it sends. ${ }^{59}$ Critics decry the ineffectiveness of various provisions of the statute and its intrusion into subject areas that traditionally have been within the province of the states. ${ }^{60}$ With respect

56. Id. at 3 .

57. See GAO Consideration, supra note 31 , at 58 (recommending that the Commission assess the sufficiency of available guidance on management's assessment of internal control); SEC Next Steps, supra note 37 (announcing a series of actions intended to "improve the implementation of the Section 404 internal control requirements of the Sarbanes-Oxley Act" in response to comments from a variety of sources).

58. See Concept Release on Internal Control, supra note 54 (discussing the Commission's efforts to gain public comment); ADVISORY COMMITTEE REPORT, supra note 34, at 23 (stating that small businesses particularly need guidance); SEC, PCAOB Roundtable on Sarbanes-Oxley Says Second Year Better, Guidance Needed, 74 U.S.L.W. 2677, 2677 (May 16, 2006) (noting continued need for clearer guidance).

59. See, e.g., James D. Cox, The Role of Empirical Evidence in Evaluating the Wisdom of the Sarbanes-Oxley Act, 40 U.S.F. L. REV. 823, 844 (2006) (praising SOX for providing "a coherent core of concepts designed to strengthen the financial reporting process"); Donald C. Langevoort, Internal Controls After Sarbanes-Oxley: Revisiting Corporate Law's "Duty of Care as Responsibility for Systems," 31 J. CORP. L. 949, 950 (2006) (expressing that although SOX will have positive results generally in enhancing corporate transparency and specifically in improving financial reporting quality, the determination of whether the benefits are worth the costs depends on the intended beneficiaries of the legislation); Lawrence E. Mitchell, The Sarbanes-Oxley Act and the Reinvention of Corporate Governance?, 48 VILL. L. REV. 1189, 1189 (2003) (applauding SOX for, among other things, bringing various gatekeepers such as lawyers and analysts into the corporate governance system); Joel Seligman, No One Can Serve Two Masters: Corporate and Securities Law After Enron, 80 WASH. U. L.Q. 449, 516 (2002) (expressing belief that the core provisions of SOX, relating to auditor independence, audit committees, financial reporting, analyst conflicts of interest, and Commission resources, are a thoughtful and well drafted response to the corporate scandals).

60. See, e.g., William J. Carney, The Costs of Being Public After Sarbanes-Oxley: The Irony of "Going Private," 55 EMORY L.J. 141, 141-42 (2006) (suggesting that SOX's reach beyond disclosure requirements into internal corporate governance may cause smaller companies to rethink their decision to become public); Larry E. Ribstein, Market vs. Regulatory Responses to Corporate Fraud: A Critique of the Sarbanes-Oxley Act of 2002, 28 J. CORP. L. 1, 3 (2002) (arguing that 
to SOX 404 specifically, although some businesses and governmental agencies have expressed the belief that SOX 404 has increased public companies' financial reporting accuracy, ${ }^{61}$ reaction to SOX 404 has been more uniformly critical. The prevalent sentiment is that the benefits of SOX 404 are meager and difficult to measure, and that those few and unquantifiable benefits have been derived from substantial and tangible costs of compliance. ${ }^{62}$ Former SEC Chairman Harvey Pitt, recognizing the economic burdens imposed by SOX 404, has summed up corporate America's sentiment that SOX 404 is "reviled here and abroad." 63

\section{A. Implementation Costs}

Reports by congressional auditors and an advisory committee to the Commission have acknowledged that costs for public companies to comply with SOX 404 have been much higher than anticipated. ${ }^{64}$ Among the costs of SOX 404 compliance have been the loss of senior

contract and market approaches will be more efficient in monitoring and preventing fraud than SOX's regulatory approaches); Roberta Romano, The Sarbanes-Oxley Act and the Making of Quack Corporate Governance, 114 YALE L.J. 1521, 1526-29 (2005) (criticizing the lack of empirical support for SOX by citing results from studies on audit committee independence, executive loans, and auditors' non-audit services); Robert B. Thompson \& Hillary A. Sale, Securities Fraud as Corporate Governance: Reflections upon Federalism, 56 VAND. L. REV. 859, 861 (2003) (pointing to SOX as an example of the "ascendancy of federal law in corporate governance").

61. See ADVISORY COMMITTEE REPORT, supra note 34, at 108 n.218, 126 (indicating that some advocates of Section 404 have pointed to the 1200 financial restatements in 2005 , doubling the number from 2004, as evidence of the provision's positive effect in improving financial reporting accuracy, while critics of Section 404 have responded by questioning why many of those companies who claimed effective internal controls and received clean auditor attestations in 2004 have had to withdraw their financial statements for restatement in 2005); FIN. EXECUTIVES INT'L, FEI SURVEY ON SARBANES-OXLEY SECTION 404 IMPLEMENTATION: EXECUTIVE SUMMARY 3 (2006), available at http://www2.fei.org/files/spacer.cfm?file_id=2104 (reporting that $38.4 \%$ of 274 financial executives believed that their companies' financial reports are more accurate as a result of complying with SOX 404); Christopher A. Myers \& Kwamina Thomas Williford, SEC and PCAOB Move Toward "RiskBased" Approach to Sarbanes-Oxley Section 404 Compliance, 5 Corp. Couns. Wkly. (BNA) 40, 40 (Jan. 31, 2007) (referencing reports by the Public Company Accounting Oversight Board and the Commission that SOX 404 has resulted in more accurate financial statements).

62. See ADVISORY COMMITTEE REPORT, supra note 34, at 7, 125-26 (discussing comments from public companies that SOX 404 provides little or no benefits); U.S. GOV'T ACCOUNTABILITY OfFICE, GAO-06-255R, INTERNAL CONTROL: ANALysis OF JOINT STUDy ON Estimating THE COSTS AND BENEFITS OF RENDERING OPINIONS ON INTERNAL CONTROL OVER FINANCIAL REPORTING IN THE FEDERAL ENVIRONMENT enclosure I, at 23 (2006) [hereinafter GAO ANALYSIS] (discussing significant costs from internal control opinions and difficulty in determining benefits from the opinions); Robert Charles Clark, Corporate Governance Changes in the Wake of the Sarbanes-Oxley Act: A Morality Tale for Policymakers Too, 22 GA. ST. U. L. REV. 251, 291-95 (2005) (discussing five points that raise doubts about whether the benefits of SOX 404 exceed its costs).

63. Pitt, supra note 50.

64. ADVISORY COMMITTEE REPORT, supra note 34, at 32; see also GAO CONSIDERATION, supra note 31 , at 14-18 (comparing compliance costs of smaller and larger public companies). 
management's time that could otherwise be spent in strategic decisionmaking to maximize shareholder value, the disincentives for start-up companies to go public, the costs of domestic issuers going private, and the loss of foreign issuers who are not listing on the United States exchanges or are leaving the United States market. ${ }^{65}$ In addition, the requirements of SOX 404 have created disincentives for companies to undertake certain business initiatives, such as mergers, acquisitions, product development, and technology upgrades, because of the fear that those activities will entail additional accounting controls that would need to be implemented, documented, tested, assessed, and audited. ${ }^{66}$

In addition to these far-reaching, unintended opportunity costs of SOX 404 compliance, the immediate monetary outlays for the management assessments and auditor attestations of ICFR have been painfully high. ${ }^{67}$ In its release to adopt the implementation rules for SOX 404, the Commission estimated that the average annual cost of compliance over the first three years would be $\$ 91,000$ per company. ${ }^{68}$ The average annual costs actually incurred by public companies during the first two years of implementation, without dispute, have been drastically higher than anticipated.

65. See GAO CONSIDERATION, supra note 31, at 17, 21-26 (discussing that some companies attribute their decision to go private to SOX, and that some chief financial officers and accounting staff spend as much as ninety percent of their time on SOX 404 compliance efforts during the first round of SOX 404 filing); Kip Betz, NYSE CEO Expects SOX Changes to Aid Compliance Coming 'Relatively Soon,' 38 Sec. Reg. \& L. Rep. (BNA) 1708, 1708 (Oct. 9, 2006) (stating that twenty-four out of the twenty-five largest initial public offerings in 2005 were listed on overseas exchanges); Carney, supra note 60, at 157 (finding that going-private filings almost doubled in the years following enactment of SOX, with 65 filings in 2001, 59 filings in 2002, 101 filings in 2003, and 114 filings in 2004); Clark, supra note 62, at 294 (expressing concerns that SOX 404 has caused some smaller public companies to go private and other smaller companies to be deterred from going public); Law Professors Decry Sarbanes-Oxley as 'Debacle,' Call for 'Re-Examination,' 74 U.S.L.W. 2567, 2567 (Mar. 28, 2006) (citing that in 2005, there were 129 new foreign listings on the London Stock Exchange, six on the New York Stock Exchange, and fourteen on the NASDAQ Stock Market, with almost half of the new foreign listings citing SOX as the reason they listed on the London Stock Exchange); Romano, supra note 60, at 1588-89 (finding potential loss of financing opportunities as SOX deters smaller companies from going public or from being acquired by larger public companies); Kara Scannell \& Deborah Solomon, Business Wins Its Battle to Ease a Costly Sarbanes-Oxley Rule, WALL ST. J., Nov. 10, 2006, at A1 (stating that only three out of the largest twenty initial public offerings in the first ten months of 2006 occurred in the United States, compared with nine out of the largest twenty initial public offerings occurring in 2002 prior to the enactment of SOX).

66. See GAO CONSIDERATION, supra note 31, at 17 (reporting that smaller public companies canceled operational improvements and information technology investments); SEC's Atkins Concerned over Proposal for Reporting Nonexecutive Compensation, 75 U.S.L.W. 2025, 2026 (July 11, 2006) (reporting that companies have avoided acquisitions, technology upgrades, and new product lines).

67. See Final Rule on Internal Control, supra note 16, at 36,657 (recognizing "the magnitude of the cost burdens").

68. Id. 
Charles River Associates, a consulting group for the Big Four accounting firms, ${ }^{69}$ conducted a study of the costs to comply with SOX 404 in the second year of implementation for the public companies already subject to SOX 404 requirements. ${ }^{70}$ Results showed that larger public companies, those with market capitalization of more than $\$ 700$ million, spent nearly $\$ 4.8$ million on average to conduct the required management assessment and auditor attestation of ICFR. ${ }^{71}$ Smaller public companies, those with market capitalization between $\$ 75$ million and $\$ 700$ million, spent $\$ 860,000$ on average to meet their obligations under SOX $404 .{ }^{72}$ These numbers reflect a decrease from year-one implementation costs of $\$ 8.5$ million and $\$ 1.2$ million (for large and smaller public companies, respectively), which include one-time start-up expenses and the learning-curve costs that typically occur with new reporting requirements. ${ }^{73}$ A study conducted by Financial Executives International, a professional association for corporate financial executives, showed similar results. ${ }^{74}$

Despite the decrease in costs from the first year to the second year of compliance, the cost of compliance remained high. ${ }^{75}$ With first-year expenditures for SOX 404 compliance being much more extensive than the estimated $\$ 91,000$, and second-year decreases being much less than hoped for, it is not surprising that more than eighty-five percent of public companies perceive the costs of SOX 404 compliance exceed the benefits of this regulatory reform effort. ${ }^{76}$

\section{B. Wrong Focus on Internal Control Activities}

The high cost of SOX 404 compliance resulted because public companies focused their assessments on the wrong component of internal

69. The Big Four accounting firms are PricewaterhouseCoopers, Deloitte \& Touche, Ernst \& Young, and KPMG. CRA INT'L, SARBANES-OXLEY SECTION 404 COSTS AND IMPLEMENTATION ISSUES: SPRING 2006 SURVEY UPDATE 2 (2006), available at http://www.s-oxinternalcontrolinfo. com/pdfs/CRA_III.pdf.

70. See id. at 2 (providing "data on the companies" total audit fees, which are comprised of fees for the financial statement audit, the Section 404 audit of internal control, and other audit services").

71. Id. at $2-3$.

72. Id.

73. See id. at 3, 13 (listing reasons cited for the decline in year-two implementation costs).

74. See FIn. EXECUTIVES INT'L, supra note 61 (finding average accelerated-filer company expenditures of $\$ 3.8$ million in 2005 to comply with SOX 404).

75. AdVISORY COMmitTEE RePORT, supra note 34, at 32-33; SEC, PCAOB Roundtable on Sarbanes-Oxley Says Second Year Better, Guidance Needed, supra note 58, at 2678; Scannell \& Solomon, supra note 65.

76. FIn. EXECUTIVES INT'L, supra note 61. 
control. This misdirected focus stemmed from a lack of legislative and regulatory guidance, ${ }^{77}$ as well as public companies' desire to demonstrate compliance with the rules of SOX 404 while giving short shrift to the principles and purposes behind the legislation. The lack of practical guidance from policymakers and regulators, along with the directive from the Commission that each company has the responsibility to determine the "form and level" of internal controls appropriate for its own circumstances, ${ }^{78}$ led public companies to focus on the control activities component instead of the control environment component of the internal control system in their attempts to comply with SOX 404.

SOX was enacted in response to the corporate malfeasance that exposed material weaknesses in public companies' internal control systems. ${ }^{79}$ But which component of the internal control system failed? In order to know what needs to be fixed to avoid more accounting scandals in the future, it is necessary to determine whether it was the failure of the control activities or the control environment that led to the corporate ethics scandals that prompted enactment of SOX. The corporate fraud that prompted the SOX legislation resulted from a breakdown of the control environment, the component that is the foundation of the internal control system.

The control environment of an organization includes the overall integrity, attitudes, values, and operating style of senior management regarding their responsibility to provide timely and accurate financial reports. ${ }^{80}$ These top-level soft controls are designed to check the behavior of management in the executive suites; they are not the lowlevel control activities, such as account reconciliation and inventory counting, designed to guide the daily activities of ground floor employees. In Enron and other corporate scandals, it was the executives who manipulated financial disclosures to investors and improperly enriched themselves in various ways. ${ }^{81}$ The financial manipulations and unjust enrichment did not happen by accident or incompetence. ${ }^{82}$ They

77. See supra Part II.C.

78. See StAFF StATEMENT ON InTERnAl CONTROL, supra note 52, at 2-3.

79. See Olson, supra note 23 (discussing that in passing SOX, Congress recognized the need to increase focus on internal controls over financial reporting and corporate governance).

80. See supra Part II.B.

81. See Clark, supra note 62, at 295 (attributing scandals at Enron and WorldCom to aggressive or irresponsible accounting decisions made by high-level people at those organizations). See generally ENRON: CORPORATE FIASCOS AND THEIR IMPLICATIONS (Nancy B. Rapoport \& Bala G. Dharan eds., 2004) (collecting works by various scholars and experts in the field of corporate governance).

82. See EnRon: Corporate Fiascos And Their Implications, supra note 81, at XI-XIII (“"Enron' connotes extreme greed and extreme cunning."); Clark, supra note 62, at 295. 
happened through intentionally orchestrated action taken by savvy senior management. ${ }^{83}$ These business leaders' shortcoming was not a lack of due care in establishing internal control activities, or a lack of knowledge about the intricacies of accounting rules, but a lack of basic business integrity demonstrated by bypassing internal control procedures and ignoring accounting principles. ${ }^{84}$

Unfortunately, management has for the most part been focusing heavily on internal accounting activities and paying little attention to the overall internal control environment in developing and implementing internal controls designed to comply with SOX $404 .^{85}$ The time and costs that have been expended by public companies were incurred in accounting control documentation (i.e., identifying, documenting, and mapping existing accounting activities to internal control objectives), accounting control testing (i.e., drafting test scripts, performing testing of accounting activities, and identifying and documenting internal control design and operating deficiencies), and accounting control remediation (i.e., developing deficiency remediation plans, designing and documenting internal controls to address deficiencies, and retesting accounting activities) ${ }^{86}$

The work product of SOX compliance efforts includes internal control grids identifying accounting activities and objectives, flowcharts and narratives covering key activities that affect financial statements, and testing worksheets for identifying deficiencies in the design and operation of accounting controls. ${ }^{87}$ The grids, narratives, flowcharts, and

83. See Jeffrey D. Van Niel, Enron-the Primer, in ENRON: CORPORATE FIASCOS AND THEIR IMPLICATIONS, supra note 81, at 3,13-17 (discussing the background events and circumstances surrounding the collapse of Enron).

84. See id.; Cheryl Rosen, Ethics After Enron, Bus. ETHICS, Summer 2006, at 22, 25 (pointing out that Enron had a state-of-the-art ethics program); Dennis Nally, Chairman and Senior Partner, PricewaterhouseCoopers, Remarks at the Denver Forum and the City Club of San Diego (Jan. 5-6, 2006), available at http://www.pwc.com/extweb/ncpressrelease.nsf/docid/61B76019FE4646DE $852570 \mathrm{ED} 00606 \mathrm{C} 21$ (opining that Enron executives and accountants focused on accounting rules and ignored accounting principles).

85. See AdVISORY COMmitTEe REPORT, supra note 34, at 23 (discussing problems companies generally encounter in complying with SOX 404); Clark, supra note 62, at 291-95 (discussing costs of SOX 404 compliance); Wagner \& Dittmar, supra note 23, at 135-37 (discussing approaches to SOX compliance).

86. See Concept Release on Internal Control, supra note 54, at 40,869-73; PRICEWATERHOUSE COOPERS, SARBANES-OXLEy ACT: SECTION 404 Practical GUidANCE FOR MANAGEMENT 45-75 (2004) [hereinafter PWC PRACTICAL GUIDANCE] (discussing the methodology of internal control documenting, testing, evaluation, and reporting); GAO CONSIDERATION, supra note 31, at 17; Clark, supra note 62, at 291-95; Wagner \& Dittmar, supra note 23, at 135-37.

87. This information is based on the personal experience of the author, who served as the Director of Finance and a member of the SOX Compliance Committee of a Fortune 500 company [hereinafter Author Experience]. See also PWC PRACTICAL GuIDANCE, supra note 86, at 93-105 (providing examples). 
worksheets are detailed and lengthy, identifying the specific steps and individuals involved in each activity. For example, the control grids, narratives, and flowcharts for paying an invoice may include the following details: procedures for the request, authorization, and issuance of a purchase order; steps for the receiving and recording of products into the inventory system; procedures for the receipt and posting of the invoice on the accounts payable systems; processes for performing a three-way match between the purchase order, the receiving report, and the invoice to ensure the accuracy and validity of product received and invoice pricing; procedures for making and approving a disbursement request; steps to verify the identity and validity of the vendor prior to issuance of the disbursement; and procedures to record the disbursement on the accounting systems. ${ }^{88}$

These detailed narratives, flowcharts, and documentation have to be created for all key activities that affect the financial statements, including, for example, activities in the areas of inventory, fixed assets, procurement, order processing, freight, accounts payable, accounts receivable, product costing, and payroll. ${ }^{89}$ Company personnel are required to review the narratives, flowcharts, and control grids to ensure that the company follows the processes that are documented for each accounting control, and that all of the identified accounting controls are in fact in place and operating. ${ }^{90}$ Employees are also required to test and document, on a periodic basis, all internal accounting controls that have been identified. ${ }^{91}$

The focus on internal control activities instead of the internal control environment has led public companies to identify, document, and test an excessive number of low-level accounting controls. ${ }^{92}$ External auditors, in their procedures to conduct an audit and attestation of management's

88. Author Experience, supra note 87; see also PWC PRACTICAL GUIDANCE, supra note 86, at 93-105.

89. Author Experience, supra note 87; see also PWC PRACTICAL GUIDANCE, supra note 86, at 93-105; Carney, supra note 60, at 144-45 (discussing the involvement of employees from various areas of the company in the internal control assessment process).

90. See Concept Release on Internal Control, supra note 54, at 40,869-73; PWC PRACTICAL GUIDANCE, supra note 86, at 56-68 (discussing methods to determine whether internal controls are operating); Carney, supra note 60, at 144-45; Wagner \& Dittmar, supra note 23, at 135-37.

91. See sources cited supra note 90.

92. See Concept Release on Internal Control, supra note 54, at 40,869-73; DeloitTE, ACHIEVING SOX COST REDUCTIONS THROUGH CONTROLS RATIONALIZATION: MOVING TOWARDS A LEAN AND BALANCED APPROACH IN 2006, at 2, http://jobfunctions.bnet.com/whitepaper.aspx? $\&$ docid $=237809$ \&promo $=100510$ [hereinafter LEAN AND BALANCED] (registration and login required) (discussing poll reporting $62 \%$ of participants admit having "too many controls over routine areas"); ADVISORY COMMITTEE REPORT, supra note 34, at 136; STAFF STATEMENT ON INTERNAL CONTROL, supra note 52, at 4-5. 
assessment as required by SOX 404, have also been focusing on the minutiae of control activities and requiring management to account for controls such as who attended meetings and who has access to office keys. ${ }^{93}$ The result is that auditors have identified, in one case, over 60,000 internal controls for management to document and test. ${ }^{94}$ Management's approach to identifying, documenting, and testing the low-level accounting activities has caused the large and unexpected costs of SOX 404 compliance. ${ }^{95}$ Businesses are spending millions of dollars to hire consultants and employees and to implement new computer systems to manage reams of data about internal control activities, on top of the millions of dollars that the companies pay to the external auditors to audit and attest to everything management has done. ${ }^{96}$

The Commission has stated its belief that the high costs of SOX 404 implementation have been due to the "mechanical, and even overly cautious" way that management has approached SOX 404 in a "bottomup, check-the-box approach" to assessing internal control over financial reporting. ${ }^{97}$ So instead of focusing on the top-level soft controls in the control environment that are aimed at curbing abuses carried out by company executives, the same abuses SOX 404 was designed to dissuade, public companies have been devoting their time and resources to the massive number of low-level accounting controls designed to guide the daily operation of line-level employees. Public companies' focus on internal control activities has been taken nearly to the exclusion of any assessment of the internal control environment. ${ }^{98}$

93. See Clark, supra note 62, at 294 (reciting examples of auditor recommendations arising from SOX 404 reviews to include documenting every call from employees to the technical help centers and proving appropriate controls over all office keys); Langevoort, supra note 59, at 966 (noting anecdotal evidence showing audit firms have interpreted SOX 404's requirement for auditor attestation broadly, resulting in auditors focusing on time-consuming but revenue-generating tasks); Scannell \& Solomon, supra note 65 (noting that auditors' fear of lawsuits by investors or the Commission has prompted auditors to identify excessive numbers of key internal controls).

94. Scannell \& Soloman, supra note 65.

95. See Concept Release on Internal Control, supra note 54, at 40,870-71; Clark, supra note 62, at 293-95; Scannell \& Solomon, supra note 65; Press Release, U.S. Sec. \& Exch. Comm'n, No. 2005-74, Commission Statement on Implementation of Internal Control Reporting Requirements (May 16, 2005), http://sec.gov/news/press/2005-74.htm [hereinafter SEC Statement on Implementation].

96. See sources cited supra note 95.

97. SEC Statement on Implementation, supra note 95; see also SEC Next Steps, supra note 37 (noting that "management assessments under Section 404 have not fully reflected the top-down, riskbased approach").

98. See SEC, PCAOB Roundtable on Sarbanes-Oxley Says Second Year Better, Guidance Needed, supra note 58, at 2679 (reporting panelists' calls for more risk-based controls); DELOITTE, Article: Corporate Culture and the CONTROl Environment: A Cultural AsSESSMENT LEADS TO STRONG INTERNAL CONTROL (2006), http://www.deloitte.com/dtt/article/0,1002,sid\% 253D5601\%2526cid\%253D35751,00.html (noting many "compliance projects focus on internal 
The selection of internal control activities as the focus of management's assessment is understandable. The Commission's rules require management's assessment of ICFR to include documentation and testing of ICFR. ${ }^{99}$ It is practical and achievable to document that the company has the requisite accounting activities in place, and that the accounting controls are performing as intended. Take, for example, the accounting control of segregation of duties. It is logistically simple to document that job responsibilities have been divided so that no individual employee has the duty or opportunity to both authorize and initiate a transaction, and it is also feasible to verify that transactions have in fact been initiated by the proper employee with the authorization of another employee at the appropriate level of authority. ${ }^{100}$ Focusing on internal control activities may entail much time and costs to public companies because of the sheer volume of possible accounting controls, but the process of identifying, documenting, and testing internal control activities can be practicably and demonstrably implemented because of the concrete and tangible nature of accounting controls.

The internal control environment and its associated soft controls are, however, difficult to document and test. ${ }^{101}$ How do companies document or test whether ethical fundamentals about financial reporting are operating at the senior management level? How do companies test whether their top leaders have the moral compass to steer in the right direction ethically while operating the business, executing profit strategies, and reporting financial results? The existence of codes of conduct and ethics training at companies cannot in themselves provide evidence that internal controls will be applied or that they will be effective against senior management overrides in situations of extreme pressure to meet internal projections and external market expectations. ${ }^{102}$ Not only would it be logistically difficult to document and test the ethics of senior management, but it would also be career suicide for specific employees to perform the unenviable task of documenting and reporting on the ethics of their senior management in the way that specific

control, often overlooking the control environment").

99. Final Rule on Internal Control, supra note 16, at 36,643.

100. See Clark, supra note 62, at 294-95 (giving examples of low-level controls); Carney, supra note 60, at 147 (noting increased demand for separation of functions); PWC PRACTICAL GUIDANCE, supra note 86, at 108 (presenting hypothetical assessment finding inadequate segregation of duties).

101. See ADVISORY COMMITTEE REPORT, supra note 34, at 23-24 (noting companies with more limited resources, fewer personnel, and less revenue are more likely to rely on undocumented and untested controls).

102. See KPMG Forensic, KPMG, INTEGRITY SURVEY 2005-2006, at 6 (2005), available at http://www.us.kpmg.com/RutUS_prod/Documents/9/ForIntegritySurv_WEB.pdf (attributing management misconduct to pressure to meet business targets and overriding of company policies). 
employees are currently performing the task of documenting and reporting on the effectiveness of various internal accounting activities.

\section{REFORMS FOCUSING ON CONTROL ACTIVITIES ARE INEFFECTIVE IN IMPROVING CORPORATE BEHAVIOR}

Various attempts at reform have focused on preventing corporate misconduct through structural mechanisms - processes and activities that can be objectively identified and quantified, such as ethics training, compliance committees, and accounting policies and procedures. Past reform efforts that have imposed requirements for structural mechanisms, which are similar to SOX's current focus on internal accounting activities, have not been successful in enhancing financial reporting accuracy or improving corporate integrity.

\section{A. Reform Efforts Prior to SOX}

Congress, the Commission, and the United States Sentencing Commission have mandated various structures and processes in their past reform efforts. The United States Sentencing Guidelines for Organizations, for example, has identified specific steps organizations can take to receive a reduction in fines and penalties in the event they are found guilty of violating federal criminal laws. ${ }^{103}$ These steps include establishing standards of ethical conduct, conducting training on standards of conduct, and establishing an ethics office or system for employees to report or seek guidance regarding criminal conduct. ${ }^{104}$

In addition, public companies have been subject to the requirement to keep accurate financial records and maintain a system of internal controls since the passage of the Foreign Corrupt Practices Act of 1977 ("FCPA"). ${ }^{105}$ The FCPA was passed after domestic companies' use of corporate funds for questionable or illegal payments to foreign government officers became public knowledge and "shook faith and trust in the integrity of our corporate sector." "106 As part of Congress's effort to restore the loss of faith and trust in corporate America arising out of the bribery payments, the FCPA included a requirement that public

\footnotetext{
103. U.S. SENTENCING GUIDELINES MANUAL, ch. 8, introductory cmt. (2005).

104. Id. § 8B2.1.

105. Pub. L. No. 95-213, 91 Stat. 1494 (1977) (codified as amended in scattered sections of 15 U.S.C.).

106. Foreign Corrupt Practices Act of 1977, Exchange Act Release No. 17,500, 46 Fed. Reg. 11,544, 11,545 (Feb. 9, 1981).
} 
companies establish a system of internal controls to safeguard corporate assets, maintain appropriate authorization procedures for corporate transactions, and ensure accuracy of financial records. ${ }^{107}$

The Commission issued a policy statement several years after passage of the FCPA to communicate its view that public companies, as a result of experiencing high anxiety over the broad language of the internal accounting control provision of the FCPA, had been overly cautious in ensuring technical compliance with the FCPA and had diverted corporate resources to create a burdensome system that did not necessarily reflect the principles embodied in the FCPA. ${ }^{108}$ The Commission, in extolling business leaders not to limit themselves to "nominal gestures of compliance" with the requirement to establish an internal accounting control system, but instead to assume management responsibility to foster integrity within the corporate environment, recognized that regardless of how strong a company's internal accounting controls are on paper, the internal control activities themselves will not be effective to achieve the Act's objective in the absence of a control environment that promotes integrity in financial reporting. ${ }^{109}$

\section{B. Reform Efforts Under SOX}

SOX 404 and its implementation rules, in addition to reiterating the need for public companies to establish an internal accounting control system, added more layers of processes to the FCPA by requiring management to assess and report on the company's system of internal controls and requiring auditors to conduct an audit and attestation of management's assessment. ${ }^{110}$ In light of the failure of past regulatory efforts to enhance financial reporting accuracy and corporate integrity through internal control requirements similar to those that are now in SOX 404, and the similar mode of burdensome implementation of the internal control requirements, those who expect SOX 404 to achieve its objective of restoring investor confidence and improving financial accuracy are bound to be disappointed. Indeed, the regulators themselves have acknowledged that although past reform efforts may have communicated the demand for transparency, accuracy, and timeliness in financial reporting, the requirements for structural

107. 15 U.S.C. $\S 78 \mathrm{~m}(\mathrm{~b})(2000)$.

108. See Foreign Corrupt Practices Act of 1977, supra note 106, at 11,544.

109. Id. at 11,547.

110. See supra Part II.A. 
mechanisms such as accounting policies and procedures alone have not been fully effective in fostering management accountability. ${ }^{111}$

The Commission has recognized that public companies' current approach to SOX 404 compliance has included "excessive, duplicative or misfocused efforts" and that any "approach that treats all controls equally is less likely to improve internal controls and financial reporting." "The Commission, however, has continued its attempt to reign in accounting fraud by focusing on internal accounting activities instead of redirecting the focus to the internal control environment. The Commission's answer to the excessive, duplicative, and misdirected compliance efforts has been to advise companies to focus on "controls related to those processes and classes of transactions for financial statement accounts and disclosures that are most likely to have a material impact on the company's financial statements."113 Thus, in the Commission's view, the focus of management's assessment of ICFR should continue to be on the internal accounting activities, but not the multitude of unimportant accounting activities that are currently being applied. Instead, the Commission believes the focus of management's assessment of ICFR should be on "relevant" accounting activities that are likely to have a "material impact" on the financial statements. ${ }^{114}$

Although the Commission's approach to limiting SOX 404 requirements to "material" accounting processes and transactions will alleviate some of the cost burdens of SOX 404, continuing the focus on internal accounting activities still leaves the internal control environment unaddressed. The Commission has thus far bypassed the opportunity to specify that company assessment of senior management's integrity, ethical values, professional competence, and operating style with respect to financial reporting is most needed under SOX 404. These are the elements of the internal control environment, and these are the elements that influence and direct public companies' financial reporting. Failure of the control environment is the cause of the corporate corruption that prompted the enactment of SOX, and failure to assess the control environment will not get to the root causes of fraudulent financial reporting and corporate misbehavior.

111. See GAO ANALYSIS, supra note 62, at 13 .

112. SEC Statement on Implementation, supra note 95.

113. STAFF STATEMENT ON INTERNAL CONTROL, supra note 52, at 6.

114. Id.; see also Rachel McTague, SEC Proposes Interpretive Guidance for Management's Assessment of Controls, 38 Sec. Reg. \& L. Rep. (BNA) 2107, 2107 (Dec. 18, 2006) (discussing the Commission's proposed interpretive guidance that management's assessments of ICFR should be based on materiality, with the primary thrust of the guidance to reduce costs). 


\section{Effect of Reform Efforts}

Congress, in requiring public companies to perform a management assessment and auditor attestation of the effectiveness of internal control systems, expected that the market would punish companies that report material weakness ${ }^{115}$ in their internal control systems. In theory, investors should flee these stocks, depressing offending companies' stock prices. ${ }^{116}$ The effect of SOX on investor confidence, however, has been questioned from the beginning of the statute's enactment. ${ }^{117}$ Moreover, several years after the passage of SOX, it appears either that investors are not aware of information about companies' material weaknesses in internal control activities, or are aware of the accounting weaknesses but are not letting those internal control failures affect their investment decisions. ${ }^{118}$ Although stock prices of some companies lost ground after disclosure of material weaknesses in internal accounting

115. Many Material Weaknesses Relate to Taxes, Cox Reports, 74 U.S.L.W. 2502, 2502 (Feb. 28,2006 ) (stating that "[n]early a third of companies that have reported material weaknesses in their internal controls [cited] at least one ... weakness[] . . relat[ing] to income taxes," with the causes including "inadequate application of generally accepted accounting principles for income taxes," "inadequate documentation to support the amounts recorded for such things as valuation allowances and foreign subsidiaries," "inadequate controls on calculations and reconciliations," and "inadequate policies and procedures to review complex or non-routine transactions"); SEC, PCAOB Roundtable on Sarbanes-Oxley Says Second Year Better, Guidance Needed, supra note 58, at 2677-78 (reporting that $16 \%$ of 3900 accelerated filers reported a total of 1500 material weaknesses in year one of implementation, and $7 \%$ of 3000 accelerated filers reported a total of 400 material weaknesses through April 25, 2006 for year two of implementation).

116. See Staff StATEMENT On InTERnAl CONTROL, supra note 52, at 10 ("The Commission's rule implementing [SOX] 404 was thus intended to bring information about material weaknesses in internal control over financial reporting into public view.").

117. See Law Professors Decry Sarbanes-Oxley As 'Debacle, 'Call for 'Re-Examination,' supra note 65 , at 2567 (pointing out that between the time that the public heard about the WorldCom scandal and President Bush's statement advocating stronger legislation to combat corporate fraud, the Dow Jones Industrial Average gained about 150 points; on the day of the President's statement, however, the Dow dropped 179 points; and when the Senate passed SOX a day later, the Dow fell an additional 282 points); Romano, supra note 60, at 1546-48 (doubting that the upward movement of the market in July 2002 was a result of the market's positive assessment of the enactment of SOX, by pointing out that although the year-long downward slide of the daily closing price of the S\&P 500 composite index ceased after the conference committee reported a SOX bill in July 2002, the upward climb was only temporary as the S\&P in October 2002 was back to the low level that it was at in July 2002).

118. See AdVisory COMmittee Report, supra note 34, at 140-41 (discussing the public's continuing investment in companies that are not yet subject to Section 404 requirements as evidence that investors do not care about Section 404 protections); Langevoort, supra note 59, at 962-63 (questioning the relationship between disclosure of internal financial reporting controls and securities prices). 
controls, ${ }^{119}$ the stock prices of other companies were unaffected or even increased after disclosure of such weaknesses. ${ }^{120}$

Although recent reform measures may have positively influenced corporate behavior, managerial abuse remains prevalent. The Sentencing Guidelines and FCPA did not prevent the scandals that prompted SOX, and SOX did not dissuade the managerial improprieties seen since the enactment of that legislation. In addition to the accounting schemes that have been uncovered at various companies, ${ }^{121}$ the longstanding abuses in the mutual fund industry continued after passage of SOX and came to light in 2003. ${ }^{122}$ Past corporate reforms also did not succeed in preventing or inducing discontinuance of the longstanding practice of backdating executive stock options, which came to public attention in 2005 and has resulted in a succession of corporate chiefs resigning in disgrace. $^{123}$

119. David Reilly, Checks on Internal Controls Pay Off, WALL St. J., May 8, 2006, at C3 (citing a study by research firm Lord \& Benoit showing that companies that reported no material weaknesses in either 2004 or 2005 had an average gain of $27.7 \%$ in share price during the two years ending on March 31, 2006, compared with a 17.7\% gain for the Russell 3000 share index, while companies that reported material weaknesses in both 2004 and 2005 experienced a decline of $5.7 \%$ in share prices).

120. See Deloitte Development LlC, Internal Control Disclosures: Key Trends to WATCH (2005) (on file with author) (citing analysis of data from Compliance Week's April 12, 2005 issue, which showed that of the 116 companies that disclosed material weaknesses, the impact of the disclosure on the companies' stock prices that is not explainable by random variation and overall market direction were as follows: the median price change was $0 \%$; the mean price change decreased by $0.3 \%$; the stock price of eighteen companies decreased by more than $5 \%$; and the stock price of eighteen companies increased by more than 5\%); Dave Beal, H.B. Fuller Lauds Sarbanes-Oxley, ST. PAUl PiONEER PRESS, May 21, 2006, at 1D. In late 2004, H.B. Fuller, a Minnesota-based adhesives and specialty chemicals maker, discovered discrepancies in its financial statements. On January 11, 2005, Fuller announced it would have to delay its annual financial report. When Fuller filed its annual report on February 25, 2005, Fuller disclosed details of weaknesses in its accounting controls and also restated its profits for the most recent three quarters as well as the most recent fiscal year 2004. After the disclosure of internal control weaknesses, Fuller's stock, which had been mostly in the twenty- to thirty-dollar range for years, began to climb. During the year after disclosure of its internal control weaknesses and before getting a clean assessment for 2005, Fuller's stock reached a five-year high. Beal, supra.

121. See Jennifer Bjorhus, Ex-CEO Admits Raiding Buca Till, St. PAUl PioneEr Press, June 8, 2006, at $1 \mathrm{~A}$ ("'Buca's top officers created a tone at the top and a corporate culture that allowed them to loot the company and engage in financial fraud." (quoting Linda Thomsen, SEC director of enforcement)); James M. Pethokoukis et al., AIG Fesses Up, U.S. NewS \& WoRLD REP., Apr. 11, 2005, at 36, 36 (reporting that AIG admitted to accounting irregularities intended to artificially support its stock price).

122. See Richard A. Booth, Who Should Recover What for Late Trading and Market Timing, $1 \mathrm{~J}$. BUS. \& TECH. L. 101, 104-24 (2006) (discussing abusive trading practices in the mutual fund industry and how to address the harms suffered by mutual fund investors); Tamar Frankel, How Did We Get into This Mess?, 1 J. Bus. \& TECH. L. 133, 133-38 (2006) (discussing the change in mutual fund advisory services from a profession and fiduciary service to a business and sales service).

123. See Cox: SEC Probing Over 100 Cases Involving Reporting; New Rules Halt Slide, 38 Sec. Reg. \& L. Rep. (BNA) 1567, 1567 (Sept. 18, 2006) (backdating stock options involves 
By fixating on documenting, testing, and remediating the numerous internal control activities, corporate America is tied up in demonstrating compliance with the rules that do not address the causes of fraudulent accounting practices. SOX was enacted to mollify the country's shock and disbelief over the fraudulent accounting practices of Enron, WorldCom, and other rogue corporations. The irony is that Enron executives were able to identify accounting rules to justify their financial disclosures, even though the picture of financial health that they portrayed by following those rules was distorted. ${ }^{124}$ Enron executives used the available accounting rules to mask the deteriorating conditions of the company. ${ }^{125}$ The accounting rules in those cases did not ensure that the executives would carry out their corporate and ethical responsibilities of truthful disclosure. Similarly, requiring management to assess and report on internal control activities, the same accounting policies and procedures that have been required to be in place since 1977, will not ensure that executives will carry out their ethical obligations of timely and accurate financial accounting.

\section{ASSESSING THE CONTROL ENVIRONMENT AS A NEW APPROACH TO CORPORATE REFORM}

Policymakers, when legislating and regulating to manage corporate misbehavior, impose various structural requirements. They mandate that public companies create compliance committees, implement ethics programs, establish codes of conduct, provide diversity training, and establish accounting control activities. The effectiveness of these structural fixes has been less than expected, as seen from the failure of past reform measures to prevent the corporate shenanigans of more recent years. Structural reforms do not constitute a comprehensive and effective cure for corporate ailments. In the same way that having a code

\footnotetext{
"misrepresenting the date that an option is granted so that it appears to be awarded at a time when the underlying stock price is at a low point, [thus] maximizing the potential profit to be gained when the stock option is exercised at a later date"); SEC Is Probing More than 100 Cases Involving Possible Fraud in Option Reporting, 75 U.S.L.W. 2135, 2136 (Sept. 12, 2006) (recognizing that although SOX requires real-time reporting of stock option grants, backdating has continued where options are filed late and not in compliance with statutory requirements).

124. See Edward J. Janger, Brandeis, Business Ethics, and Enron, in ENRON: CORPORATE FIASCOS AND THEIR IMPLICATIONS, supra note 81, at 63, 64-65 (summarizing Enron's manipulation of legitimate structured financing arrangements and malleable accounting rules for off-balance-sheet treatment of entities); Van Niel, supra note 83, at 13-14 (citing Enron executives' violation of the principles underlying accounting rules for special purpose entities and mark-to-market transactions); Nally, supra note 84 (opining that Enron "executives and accountants found precise [accounting] rules to justify" the disclosures they made in the financial statements).

125. See Nally, supra note 84 .
} 
of law cannot by itself ensure legal behavior, merely having a code of ethics by itself cannot ensure ethical behavior. The policies, programs, and processes that are part of a company's internal control activities can be an effective secondary defense, but a strong internal control environment must be the first defense against fraudulent financial reporting and unethical corporate behavior. ${ }^{126}$

In imposing structural requirements, policymakers avoid asking the questions that are core to the problems of management corruption and financial reporting fraud, such as how do we get business leaders to internalize an ethical mindset that will permeate and infuse the corporate environment with ethical behavior? How do we get business executives to accept the responsibility to cultivate organizational integrity not only by verbally expounding but also by actually demonstrating high ethical behavior? To ask these questions is to leave the realm of objective, verifiable structural efforts, and enter the subjective, murky world of ethical principles, moral compunction, and human behavior.

\section{A. The Need to Assess the Control Environment}

As currently interpreted and implemented, SOX 404 compliance means following the letter of the law that mandates the documentation and testing of ICFR. By limiting the scope of ICFR to the more easily documented and objectively testable internal accounting activities, business leaders demonstrate their compliance with the letter of the law to protect themselves from liability. Focusing on the letter of the law to document and test control activities, however, detracts attention from the more important objectives of evaluating and improving the behavior and ethics of management and the organization as a whole. ${ }^{127}$

Organizational integrity is more than the internal mechanisms, rules, and procedures established by business leaders; it must also include an evaluation of senior management's commitment and steadfastness to the principles underlying those mechanisms, rules, and procedures. As the Commission has said, not all internal controls are equal, and public companies should not be devoting their time and resources to internal controls that are not material to the financial statements. ${ }^{128}$ However, the Commission's position that public companies should focus only on

126. See Wagner \& Dittmar, supra note 23 , at 135.

127. See Langevoort, supra note 59, at 966 (predicting that control audits would focus on timeconsuming tasks such as documentation and testing, while leaving intact management autonomy in areas with high risk of managerial opportunism).

128. See Staff Statement on InTERnal Control, supra note 52, at 5-6. 
internal control activities that are likely to have a material impact on the financial statements ${ }^{129}$ will fall short of the Commission's goal of preventing financial fraud. The Commission can best achieve SOX 404's goal of financial reporting accuracy and fraud prevention by requiring public companies to assess the internal control environment of the company - the environment in which senior management operates and perpetuates its approach to financial reporting and public disclosure. ${ }^{130}$

Establishing internal control activities without more will not secure executive adherence to those controls. Instead, senior management has the ability to override or bypass these internal control activities, thereby rendering ineffective the very internal control activities that they established. ${ }^{131}$ Merely establishing an ethics program under the Sentencing Guidelines ${ }^{132}$ or adopting a code of ethics under Section 406 of $\mathrm{SOX}^{133}$ is not likely to decrease the likelihood that unethical managers will override controls. ${ }^{134}$ As the Antifraud Programs and Controls Task Force of the American Institute of Certified Public Accountants has advised, "[m]any financial statement frauds have been perpetrated by intentional override by senior management of what might otherwise appear to be effective internal controls." 135

Since the passage of SOX, the number of employees in positions of managing ethics and compliance programs has increased exponentially. ${ }^{136}$ Although most large organizations established formal ethics or legal compliance programs prior to the enactment of SOX, ${ }^{137}$ some organizations have added to their compliance structure by creating specific "Sarbanes Compliance Offices," with dozens of full-time employees to oversee SOX 404 compliance efforts. ${ }^{138}$ Other

\footnotetext{
129. See id.

130. See Olson, supra note 23.

131. COSO INTEGRATED FRAMEWORK, supra note 39, Executive Summary, at 6.

132. See U.S. SENTENCING GUIDELINES MANUAL, supra note 103, § 8B2.1.

133. Sarbanes-Oxley Act of $2002 \S 406,15$ U.S.C. $\$ 7264$ (Supp. IV 2004).

134. See Antifraud Programs \& Controls Task Force, Am. Inst. of Certified Pub. ACCOUntants, Management Override of Internal Control: The ACHILles' HeEl OF Fraud PREVENTION 6 (2005), available at $\mathrm{http} / / /$ www.aicpa.org/audcommctr/download/achilles_heel.pdf.

135. Id. at 1 .

136. Rosen, supra note 84, at 24 (reporting that membership in The Ethics and Compliance Officer Association, a professional organization for managers of ethics and compliance programs, has increased over 70\%, to 1260 members, in the five years since the collapse of Enron).

137. See Ethics Res. Ctr., National Business Ethics Survey 2003: How EMPloyeEs VieW ETHICS IN THEIR ORGANIZATION 5-12 (2003) [hereinafter BuSINESS ETHICS SURVEY] (comparing organizations' ethics programs between 2000 and 2003).

138. LEAN AND BALANCED, supra note 92, at 1.
} 
organizations follow the advice of consulting firms and designate employees from tax, finance, accounting, legal, internal audit, information technology, sales, marketing, and other operational departments to be responsible for internal controls relating to each employee's area of responsibility. ${ }^{139}$ The effectiveness of these ethics and compliance employees in preventing unethical management action is, however, questionable. They likely do not have the positional stature or organizational influence to challenge the actions of the senior executives. ${ }^{140}$

Some organizations have established ethics and compliance programs merely to enable company executives to "check off" that they have complied with regulatory standards such as the Sentencing Guidelines. ${ }^{141}$ Enron, for example, used its state-of-the-art ethics and compliance program as a structural front behind which the company concealed manipulative and fraudulent accounting practices. ${ }^{142}$ In addition, Enron's executives were articulate businessmen who were able to enunciate precepts for ethical business conduct while concealing their own ethical shortcomings from the outside world. ${ }^{143}$ As apparent from the continuing corporate malfeasance, ethical corporate behavior does not necessarily follow from the existence of control activities such as authorization policies, codes of conduct, or compliance committees. ${ }^{144}$ Rather, organizational conduct is dictated by whether executives enforce authorization policies, adhere to codes of conduct, and cultivate high standards of corporate behavior as demonstrated in their everyday operation and decision-making. The daily behavior of the business leaders reveals whether the company's internal controls are actually alive

139. See PWC PRACTICAL GUIDANCE, supra note 86, at 3-5.

140. See Rosen, supra note 84, at 24.

141. See Linda Klebe Treviño, Out of Touch: The CEO's Role in Corporate Misbehavior, 70 BROOK. L. REV. 1195, 1197 (2005) (emphasizing the key role of the chief executive officer in managing corporate ethics).

142. See Lynne L. Dallas, Enron and Ethical Corporate Climates, in ENRON: Corporate FIASCOS AND THEIR IMPLICATIONS, supra note 81, at 187, 198 (noting that Enron had an anonymous hotline and a code of ethics the company required its employees to sign, and that the company's espoused values of "Respect, Integrity, Communication, and Excellence" were displayed on banners in the lobby of Enron's headquarters and printed on inspirational gifts to employees).

143. See id. at 199 (stating that Enron executives adopted a compliance-based approach to follow the letter of the law, rather than a values-based approach that promoted the intent of the law); Duane Windsor, Business Ethics at "The Crooked E," in ENRON: CORPORATE FIASCOS AND THEIR IMPLICATIONS, supra note 81, at 659, 660 (noting that Enron executives' motives and conduct were contrary to their publicly professed high ethical standards).

144. See Treviño, supra note 141 , at 1201 (noting that establishing a "formal ethics or legal compliance program, by itself, does not guarantee effectiveness"). 
and operating or are merely a static structure without real-life application. ${ }^{145}$

As new and uncertain as it may be, we need to move beyond the current approach of viewing structural mechanisms as indication of, or motivation for, ethical corporate behavior. The existence of structural mechanisms merely demonstrates compliance with the requirements to establish those structural mechanisms. This is obvious from the ability and ingenuity of corporate executives to give all appearances of proper behavior through compliance with structural requirements, while contemporaneously executing schemes that are the antithesis of those very same structural mechanisms. The meager benefits realized from establishing structural mechanisms reveal that we somehow need to get to the moral and behavioral characteristics of business leaders who determine and direct the action of the organization. To obtain an understanding of the ethical dimensions of executives, we need to be able to ascertain whether executives follow the internal rules they have established, whether they live up to the values they expound, and whether they are guided by principles of business ethics that apply regardless of whether there are external rules under which they could justify questionable behavior.

\section{B. Conducting the Employee Assessment}

Employees, with their inside access and exposure to executive action on a routine basis, can be the answer to our need to understand executives' views of their obligations to the company and its stakeholders, their faithfulness to the internal rules and structural mechanisms they purportedly establish and implement, their philosophy about legal compliance, and their perspective about personal rewards and executive entitlement. The signals emanating from executives' conduct in making routine decisions and resolving issues on an ongoing basis can be a strong indication, although admittedly not a guarantee, of how well their ethics and integrity will stand up when challenging situations arise that test their values.

Employee assessment of senior management's ethics and integrity should be conducted on a company-wide basis. The inclusion of the entire employee base assures a review of business leaders throughout the organization. Also, the survey should cover the entire employee

145. See id. at 1203, 1205 (categorizing leaders who verbally espouse ethical values but do not take ethical action as "hypocritical leaders," whereas leaders who neither espouse nor conduct themselves ethically are "unethical leaders"). 
population broadly in order to separate idiosyncratic views from those that represent the company as a whole. An independent party outside of the organization should be retained to review the survey responses and prepare a composite profile of senior management of the company. Using an outside party to compile the employee responses is more likely to produce an overview of the organization that is unbiased by personal agendas and internal politics. In these company-wide surveys, maintaining the anonymity of the employee making the assessment encourages frank reflection and disclosure. By ensuring confidentiality, the survey is more likely to be successful in soliciting details that can identify patterns of management behavior and convey the ethical characteristics of the management group as a whole.

The company-wide employee assessment that this Article proposes is different from the current practice of some companies in surveying the control environment of their organization. Very few companies attempt to perform an evaluation of the organization's integrity, and those that attempt to gauge the ethics of their senior management do so by having internal employees interview the executives of the company. ${ }^{146}$ Using internal employees to interview executives about the executives' ethics is an exercise in futility for the purposes of assessing, predicting, or preventing unethical behavior. It is improbable that executives will reveal their motivation or inclination for self-enrichment and fraudulent conduct to the interviewer; the most that can be gained from any executive's answers would be an understanding of her espoused ideology. It also is highly unlikely that internal employees who have been designated to interview executives will have any political power or practical influence to voice concern about the integrity of their senior bosses.

The overall objective of the employee assessment would be to get information, from the insider-employee perspective, about the attitudes, values, and conduct of senior management and the organizational culture resulting from those attitudes, values, and conduct. The information obtained from the survey responses can then be communicated to the public. Although tailoring specific questions that should be included in an employee survey is beyond the scope of this Article, the general themes for assessment in the survey should include, at the very least, the following: how the executives promote or reward themselves and other employees; what behaviors are endorsed or permitted at the management

146. See Wagner \& Dittmar, supra note 23, at 134 (referencing examples of companies that use their own internal auditors to conduct interviews of senior executives to illustrate the condition of the companies' control environment). 
and line employee levels; the company's truthfulness and fairness in dealing with its customers and suppliers; the company's sensitivity to and treatment of conflict-of-interest transactions; how senior management treats employees with dissenting views or those who bring forth concerns about wrongdoing; the attention and speed with which the company investigates or covers up warning signs and information about wrongdoings; how tightly senior management controls information within the organization; the timeliness, completeness, and accuracy of information that the company discloses externally; and the senior executives' adherence to internal company policies and procedures as well as external laws and regulations. ${ }^{147}$

Employee surveys have gained in popularity and have been used widely by businesses for many different purposes; the logistics of conducting employee assessments are not difficult. ${ }^{148}$ Various consulting, governance, and accounting service providers have understood the critical need for an assessment of their organization's control environment, and they have developed surveys that can be used as a template in the creation of a uniform tool for all companies to assess and report on the attitudes, values, and operating style of senior executives and the ethical climate of the company as a whole. ${ }^{149}$ As

147. Because the focus of SOX 404 is on financial reporting, the Commission's definition of ICFR does not encompass a company's controls to ensure compliance with laws and regulations, other than laws and regulations directly related to the preparation of financial statements. See Final Rule on Internal Control, supra note 16, at 36,640. The company-wide survey of senior executive behavior proposed in this Article, however, should not be limited to laws and regulations relating to accounting and financial statements but should include all laws and regulations applicable to the company.

148. See generally KPMG FORENSIC, supra note 102, at 23-25 (describing survey containing 155 close-ended questions to examine the risks of fraud and misconduct inside organizations and the effectiveness of programs and controls to mitigate those risks); EMERGE International, Frequently Asked Questions About the Cultural Health Indicator, http://www.emergeinternational. com/content/CHI FAQS.html (last visited Aug. 22, 2007) (describing survey that consists of several open-ended questions and lists of statements to address nine dimensions of organizational culture: leadership, relationships, communication, infrastructure, involvement and decision-making, change management, finance, cultural descriptions, and general climate); Opinion Research Corporation, U.S. Market Research and Advisory Services, http://www.opinionresearch.com/us/about.aspx (last visited Aug. 22, 2007) (providing surveys in corporate branding, customer loyalty, market analytics, and organizational diagnostics); The Business Research Lab, Employee Surveys, http://www.busreslab.com/employeesurveys.htm (last visited Aug. 22, 2007) (including surveys on employee satisfaction, productivity, diversity, culture, health and safety, and internal customers); Watson Wyatt, Data Services, http://watsonwyatt.com/services/servicerender.asp?ID=16496 (last visited Aug. 22, 2007) (collecting, analyzing, and publishing data on compensation, benefits, and employment practices).

149. See Ethics Resource Center, ERC Surveys and Benchmarking, http://www.ethics.org/ research/surveys-and-benchmarking.asp (last visited Aug. 17, 2007); The Business Research Lab, Corporate Ethics Surveys, http://www.busreslab.com/ethics-surveys.htm (last visited Aug. 17, 2007); Watson Wyatt, Services: Human Capital/Organization Effectiveness, http://www. 
discussed above, a challenge that survey providers have faced has been to convince senior management to conduct an assessment of their own integrity, and then to conduct the survey in such a way that the results do not merely reflect the espoused views of senior management.

Questionnaires developed by providers of ethics surveys are a good starting place for formulating questions that should be included in a standard form employee assessment to be conducted by all public companies. Currently available surveys include questions in which employees are asked to rank the level of their agreement or disagreement with statements relating to management's commitment to comply with laws and regulations applicable to the company's business, the extent to which management embraces ethical values in their conduct beyond mere compliance with laws, the consistency between the statements and actions of management, the likelihood of retaliation by management for employee reporting of questionable conduct, management's level of tolerance for unethical behavior, the likelihood and consistency with which management disciplines unethical behavior, management's willingness to listen and respond appropriately to problems or bad news, the employee's feeling of pressure from other employees and management to behave in an unethical manner, and the frequency with which the employee witnesses questionable behavior on the part of other employees and management. ${ }^{150}$ The risk of unethical behavior on the part of an organization can be assessed by understanding, through culling the employee responses to a well developed set of survey questions, how employees view their management's standards of integrity and dedication to ethical fundamentals.

Employee assessments can be conducted at a very small financial cost compared to the current expenditures by public companies to comply with SOX 404 . The charges by service providers vary, ranging upward from five dollars to seventy-five dollars per employee surveyed. ${ }^{151}$ Pricing for employee surveys depends on the number of

watsonwyatt.com/services/servicerender.asp?ID=10517 (last visited Aug. 17, 2007).

150. See Deloitte Development LlC, Corporate Culture and the Control ENVIRONMENT: THE FOUNDATION OF INTERNAL CONTROL (2004), available at http://www. deloitte.com/dtt/cda/doc/content/us_assur_ethicsCulture.pdf; EMERGE InT'L, CULTURAL HEALTH INDICATOR REPORT: SAMPLE REPORT, available at http://www.emergeinternational.com/pdf/ ExampleReport.pdf; BUSINESS ETHICS SURVEY, supra note 137; KPMG FORENSIC, supra note 102; LRN, LRN ETHICS STUDY: THE EFFECT OF ETHICS ON ABILITY TO ATTRACT, RETAIN AND ENGAGE EMPLOYEES (2006) [hereinafter LRN ETHICS STUDY].

151. See E-mail from Gregg Campa, The Business Research Lab, to Deborah Hackerson, Reference Librarian, William Mitchell College of Law (Dec. 12, 2006, 4:05 p.m.) (on file with author); E-mail from Lizz Pellet, CEO, EMERGE International, to Deborah Hackerson, Reference Librarian, William Mitchell College of Law (Oct. 20, 2006, 2:42 p.m.) (on file with author). 
participants, the collection methodology (i.e., web-based, paper, or combination), the number of data sorts, the number of charts and graphs, and the extent of written commentary highlighting strengths and weaknesses. ${ }^{152}$ Overall, the pricing for employee surveys, even for those public companies with the largest employee bases, will not likely exceed the $\$ 91,000$ that the Commission estimated as the average annual cost of SOX 404 compliance. The costs for conducting employee surveys will definitely be much less than the millions of dollars the average public company is spending to assess internal accounting activities.

\section{Employee Assessments Are Effective in Evaluating Corporate Behavior}

Stakeholders are interested in corporate integrity. As the company's primary stakeholder, the investors' heightened concern over organizational ethics and social responsibility is demonstrated in their increased interest in the ethical and social dimensions of investment opportunities. ${ }^{153}$ Investment portfolios that pick companies based on their ethical or social reflection towards issues such as employment opportunity, diversity, religion, human rights, health and safety, and environmental protection have gained more attention and more popularity in recent years. ${ }^{154}$ In the past decade, "assets involved in [socially responsible] investing have risen four percent faster than all professionally managed investment assets in the United States," and the number of socially responsible investment choices has almost quadrupled from 55 mutual funds in 1995 to 201 mutual funds in $2005 .{ }^{155}$

The heightened concern about corporate conduct is also reflected in the increased popularity and attention to corporate rankings on ethical and social responsibility scales. Numerous organizations conduct annual evaluations and rank companies based on factors such as community service, workplace democracy, gender and racial diversity, and

152. See sources cited supra note 151 .

153. See generally SOC. InV. ForUM, 2005 REPORT ON SOCIALly RESPONSIBLE INVESTING TRENDS IN THE UNITED STATES: 10-YEAR REVIEW iv-vi (2006) (summarizing the scope and scale of socially responsible investing from 1995 to 2005).

154. See id. at 2-3 (defining "social investing, ethical investing, mission-based investing, or socially aware investing" as an investing approach focusing on "'open and transparent business practices that are based on ethical values and respect for employees, communities, and the environment"' (quoting Prince of Wales Business Leaders Forum)).

155. Id. at 1, 7. Socially responsible investment portfolios used screening, shareholder advocacy, and community investing to deploy the $\$ 2.3$ trillion under professional management in 2005. Id. at 1. 
environmental stewardship. ${ }^{156}$ Prompted by frequent revelations of market manipulation and other corrupt behavior by corporate actors, various industry, investor, and international groups also have crafted guidelines for corporate conduct. Examples of these guidelines include the Caux Round Table Principles for Business, the Interfaith Center on Corporate Responsibility's Principles for Global Corporate Responsibility, the United Nations Global Compact, the Consumer Charter for Global Business, the Fundamental ILO Conventions, and the OECD Guidelines for Multinational Enterprises. ${ }^{157}$ While these various corporate rankings and guidelines may differ in focusing on particular industries ${ }^{158}$ or protecting specific constituencies, ${ }^{159}$ they all reflect the same increasing concerns about fundamental business ethics and the apparent need for tools to promote corporate responsibility.

The proliferation of social investment portfolios, ethics and social responsibility rankings, and corporate conduct guidelines reflects the public's desire for more information and influence into the organizational integrity of corporate America. These attempts to glimpse into the ethical psyche of the company demonstrate that investors care not only about the end results of their investments, but also the integrity with which the company goes about achieving those results. The rankings and ratings conducted by investment portfolios, business organizations, and industry groups, however, are seen from the outsider's view. These views are formed primarily by outsiders looking at the structural mechanisms present at the company, such as the existence of codes of conduct and the establishment of ethics training programs. Although some of the ratings and rankings from external reviewers might reflect interviews and comments from a handful of internal employees, most of these interviews are of corporate executives or the employees responsible for creating and overseeing ethics programs. ${ }^{160}$ These

156. See Peter Asmus, 17th Annual Business Ethics Awards, Bus. ETHICs, Fall 2005, at 15, 1520 (mentioning Business Ethics magazine's ranking of one hundred companies for being good corporate citizens and profiling companies winning awards in categories based on the companies' corporate social responsibility management, workplace democracy, environmental excellence, and community service); Julie Forster, When Nurturing Works, St. PAul PiOneER Press, Sept. 26, 2006, at 1C (discussing Working Mother magazine's ranking of the top one hundred places to work, based on compensation of women, leave time for new parents, child care and adoption assistance, elder care assistance, and flexibility in work schedules and telecommuting).

157. Lynn Paine et al., Up to Code: Does Your Company's Conduct Meet World-Class Standards?, HARV. Bus. REV., Dec. 2005, at 122, 122-24.

158. See id. at 126-28 (describing the differences between various codes).

159. See, e.g., Forster, supra note 156 (discussing ranking of family-friendly employers).

160. See Asmus, supra note 156 (including interviews conducted with executives and compliance officers). 
individuals' objectivity may be tempered, and their views, if not biased, may not capture the perspectives or experiences of the entire employee base. Indeed, research has shown that views of organizational ethics are rosier at the top, with executives expressing more satisfaction than lower level employees regarding their organization's response to reporting of ethical violations, the level of honesty at the company, and management's accountability for ethical misconduct. ${ }^{161}$

Corporate ethics and organizational integrity are concerns among customers and employees as well. A company's ethical reputation affects the purchasing decisions of customers. Nearly $75 \%$ of people expressed a preference for making purchases from companies with ethical business practices rather than from companies with questionable business practices, even when the prices of the ethical company are higher than the prices of the company with questionable practices. ${ }^{162}$ In addition, 94\% of employees expressed that it is "critical" or "important" that their corporate employer is ethical, and $82 \%$ of employees indicated that "they would prefer to be paid less and work for a company with ethical business practices than receive higher pay at a company with questionable ethics." $" 163$

Not only do investors and employees have a common concern for ethical corporate behavior, they also have a mutual financial interest. Investors are interested in profits undiminished by senior management self-enrichment or corporate bankruptcy, and employees are interested in job continuity $^{164}$ and pension benefits ${ }^{165}$ unaffected by senior management self-enrichment or corporate bankruptcy. These common concerns and common interests provide powerful incentive for internal

161. BUSINESS ETHICS SURVEY, supra note 137, at 47, 51, 53; see also Treviño, supra note 141, at 1208-09 (noting that senior managers have more positive perceptions of the company's ethics when compared to the perceptions of non-management employees).

162. LRN Ethics Study: Ethics Impact on Purchase and Investment Decisions, http://www.lrn. com/index 2 .php?option $=$ com_content\&task=view\&id=122\&pop $=1 \&$ page $=0 \&$ Itemid $=174$ (registration and login required) (last visited Aug. 22, 2007).

163. LRN ETHICS STUDY, supra note 150, at 1.

164. See BUSINESS ETHICS SURVEY, supra note 137, at v (stating young employees' concerns that "unethical actions of top executives will jeopardize their job security").

165. See Steven Harmon Wilson, Malefactors of Great Wealth: A Short History of "Aggressive" Accounting, in ENRON: CORPORATE FIASCOS AND THEIR IMPLICATIONS, supra note 81, at 41, 41 (stating that Enron's collapse resulted in thousands of employees losing their jobs and retirement savings); Daniel Altman, Experts Say Diversify, but Many Plans Rely Heavily on Company Stock, N.Y. TimES, Jan. 20, 2002, § 1, at 26 (reporting that Enron employees who participated in the company's 401(k) plan invested their money mostly or entirely in Enron stock); Gretchen Morgenson, Beware Those One-Note 401(k)'s, N.Y. TIMES, Dec. 2, 2001, § 3, at 1 (noting that about 12,000 Enron employees participated in the company's 401(k) retirement plan, which was loaded with Enron stock and which became virtually worthless upon the company's collapse). 
employees to provide external investors with information on the ethical climate and behavioral manifestations of senior management. Senior management's primary responsibility is to foster and protect organizational integrity, and stakeholders need an objective assurance of the company's adherence to fundamental business ethics. As internal stakeholders, employees can provide external stakeholders, including investors, customers, vendors, and lenders, with an assessment of senior management's ethical standards in their business practices.

Senior management sends signals to employees through everyday conduct in managing and operating the organization. This everyday conduct is more demonstrative of senior management's integrity than the structural mechanisms the executives put into place to demonstrate compliance with legal requirements. The everyday actions of those who lead the organization indicate more of their propensity for committing fraud than the reports that senior managers are required to provide regarding the company's internal accounting controls. Employees have the best access and exposure to the decisions and actions of management on a routine basis, and these internal stakeholders can provide an assessment of management's affinity for ethical behavior or inclination for ethical lapses.

\section{Employee Assessments Are Effective in Improving Corporate Behavior}

A study conducted by the Association of Certified Fraud Examiner ("ACFE") ${ }^{166}$ provides strong support that requiring companies to conduct employee assessments of management's behavior and ethics will be more effective in improving corporate behavior than requiring management to conduct assessments of internal accounting controls. The ACFE study reveals that in cases of fraud causing one million dollars or more in losses to the organization, companies discovered the fraud $43 \%$ of the time through a tip, $25 \%$ of the time through internal audits, $18 \%$ of the time by accident, $16 \%$ of the time by external audits, and only $8 \%$ of the time by internal accounting controls. ${ }^{167}$ This data shows internal

\footnotetext{
166. ASS'N OF CERTIFIED FRAUD EXAMINERS, 2004 REPORT TO THE NATION ON OCCUPATIONAL FRAUD AND ABUSE (2004), available at http://www.acfe.com/documents/2004RttN.pdf. The Association of Certified Fraud Examiners is an industry group that provides anti-fraud education, training, and examination. Id. at ii. The organization has over 30,000 members world-wide and provides anti-fraud education materials to over 180 universities. Id.

167. Id. at 21 .
} 
controls are less effective as a fraud detection tool than the voluntary provision of information through a tip.

Furthermore, whereas fraud committed by non-management employees caused a median loss of $\$ 62,000$, fraudulent schemes involving executives caused a median loss of $\$ 900,000 .{ }^{168}$ Although the losses caused by executives were high, frauds detected by internal accounting controls tended to involve small losses with a median of $\$ 40,000,{ }^{169}$ and only $6 \%$ of executive fraud was detected through internal accounting controls. ${ }^{170}$ In contrast, $43 \%$ of million-dollar schemes were revealed through a tip, ${ }^{171} 51 \%$ of executive fraud was discovered through a tip, ${ }^{172}$ and $60 \%$ of the tips about fraudulent schemes were provided by employees. ${ }^{173}$

Results from the ACFE study show the limited effect of internal accounting controls in detecting large-dollar and high-level frauds, ${ }^{174}$ the very kind of fraud that prompted the enactment of SOX and that SOX 404 was meant to deter. It is also evident from this study that employees have information that can provide a measurement of the ethical behavior of company leaders, and tapping this information through employee assessments will provide a more effective way to detect and reduce management fraud.

One structural mechanism that SOX requires companies to establish is a hotline for the anonymous reporting by employees of concerns regarding questionable accounting or auditing matters. ${ }^{175}$ A hotline for the anonymous reporting of fraudulent accounting activities is a worthy endeavor to obtain from employees information regarding specific instances of malfeasance by various parties inside the company. ${ }^{176}$ The hotline, however, is not as effective or comprehensive as a companywide employee assessment of the overall culture of ethics within the organization and senior management's loyalty to ethical standards when the executives are not on public display. ${ }^{177}$ To be effective in gaining

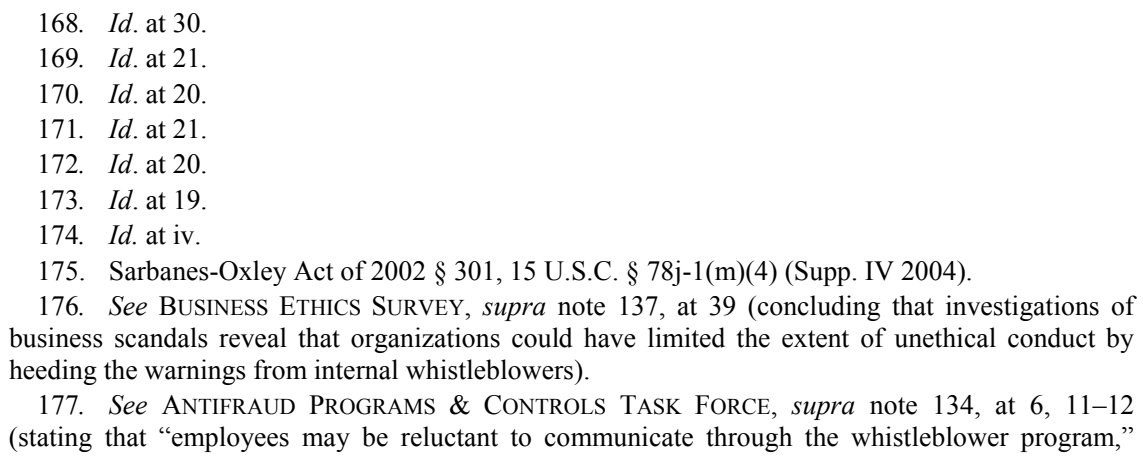


information about illegal or fraudulent activities, the hotline relies on employees to take the initiative in reporting information about specific circumstances that create concern or knowledge by the employee that an illegal or fraudulent activity has occurred. ${ }^{178}$ Individual initiative, however, is often lacking as employees are likely to experience social pressure to remain silent about wrongdoing by their supervisors and colleagues. ${ }^{179}$ Unless specifically asked to provide information, employees are unlikely to volunteer their views or perceptions about senior management's ethical lapses. ${ }^{180}$

In addition, employees often do not know whether an activity or action by senior management violates any internal requirements or external regulations such that it should be reported or even how it should be reported. ${ }^{181}$ An employee assessment, on the other hand, can provide employees with specific questions that will cull information about behaviors that indicate legal improprieties or ethical lapses from their experience inside the company and their exposure to management. Survey administrators have learned from experience that employees who respond that they have not observed misconduct when the question is

suggesting that the company's audit company should be routinely furnished with the results of employee surveys regarding corporate behavior, and encouraging audit committee members to establish communication with employees below the senior management level in order to monitor senior management behavior and control management overrides).

178. In addition to the mechanism for anonymous reporting, SOX also provides protection for corporate whistleblowers. Sarbanes-Oxley Act of $2002 \S 806$ (a), 18 U.S.C. $\S 1514$ A (Supp. IV 2004). SOX prohibits employers from taking retaliatory action against employees who provide information or assist in an investigation of conduct that the employees reasonably believe constitutes a violation of federal securities laws. Id. Although the statute purports to provide protection to employees who report of fraudulent activities, the likely success of a whistleblower's reprisal lawsuit against an employer under SOX remains to be seen. See Baynes, supra note 16, at 891 (citing success rate of $25-33 \%$ for reprisal lawsuits under federal whistleblower statutes). Moreover, SOX's goal of promoting employee reporting of fraudulent activities may be modest because of the limited substantive nature of the statute, which protects only the reporting of securities fraud and not other kinds of wrongdoing. See id. (stating that a whistleblower in a case involving a non-securities related offense must "rely on the vagaries of state law"). The statute also requires whistleblowers to fulfill numerous procedural steps for protection, including the showing of adverse employment action and filing an administrative claim with the Secretary of Labor within ninety days of the discriminatory act. See id. at 890.

179. See Business EthiCs SurveY, supra note 137, at 39, 42, 45-46 (citing fear of not being viewed as "team players" and instead being labeled as "snitches" or "troublemakers" as a reason why employees do not report misconduct).

180. See Dov Seidman, The Case for Ethical Leadership, http://www.lrn.com/index2.php? option $=$ com_content\&task $=$ view\&id $=129 \&$ pop $=1 \&$ page $=0 \& I t e m i d=174 \quad$ (registration and login required) (last visited Aug. 17, 2007). Dov Seidman is CEO and Chairman of LRN, a national provider of legal, compliance, ethics management, and corporate governance services. About LRN, http://www.lrn.com/about_lrn (last visited Aug. 23, 2007); Seidman, supra.

181. See Business EthiCs SuRvey, supra note 137, at 27, $42-43$ (citing "cynicism that nothing will be done" and lack of knowledge about whom to contact or how to report the misconduct as reasons why employees do not report misconduct). 
phrased in general terms will often respond affirmatively that they have observed misconduct when the question is specific about the form of misconduct in question. ${ }^{182}$

A company-wide employee assessment will solicit information from the employee group as a whole, without asking individual employees to step forward. Broad coverage of the employee base provides comfort to those employees who fear they will be identified if they are the only ones expressing their opinions through a hotline instead of being part of the entire employee population being surveyed. ${ }^{183}$ The anonymity of the survey takers and the compilation of results across the company will also decrease the fear of retaliation or ostracism for speaking out, and thus increase the likelihood of frank disclosure. ${ }^{184}$ Recent scandals have heightened employees' awareness that they must report evidence of illegal and unethical behavior or risk losing not only their current source of livelihood, but also their accumulated assets for retirement. ${ }^{185}$ Requiring public companies to conduct annual employee assessments and to report the results publicly will provide employees with a functional and effective process to evaluate the integrity of senior leadership and the ethical culture of the company.

A potential limitation on utilizing employee surveys to assess organizational ethics is that employees may fear that they will jeopardize the success of the company by speaking out on management misdeeds. If this fear leads employees to under-report management's unethical conduct, results from the employee assessment may be biased in a positive direction. A counterweight to the potential for under-reporting is that the employees have to assess the perceived risks from disclosing management improprieties against the risks that management misconduct, if it remains untold, will cause the depletion of the company's resources through executive self-enrichment. Worse yet,

182. See id. at 28 (listing specific types of misconduct used in survey questions, including: "Abusive or intimidating behavior toward employees"; "Lying to or withholding information from employees, customers, vendors or the public"; "Discrimination on the basis of race, color, gender, age, or similar categories"; "Stealing, theft, or related fraud"; "Sexual harassment"; "Falsifying financial records and reports"; and "Giving or accepting bribes, kickbacks, or inappropriate gifts").

183. See id. at 43 (concluding that the top two reasons given by employees for not reporting misconduct include the belief that no corrective action will be taken and the fear that their communication will not be kept confidential).

184. See id. at 39, 45 (concluding that younger employees are most likely to feel that management will retaliate or view them negatively if they report misconduct); KPMG FORENSIC, supra note 102, at 8 (reporting that approximately half of employees surveyed believed they would not be protected, or were unsure of their protection, from retaliation for reporting a violation of company standards); Treviño, supra note 141, at 1209 (stating that employees are hesitant to report unfavorable information because they fear retaliation).

185. See sources cited supra note 165 . 
management corruption may lead to the total collapse of the company similar to the demise of the companies involved in the accounting schemes that prompted SOX or the scandals that have come to light since passage of SOX.

By conducting an employee assessment and reporting the results to the public, the company can provide information regarding senior management's attitude and behavior with respect to compliance with external laws and regulations as well as internal policies and procedures. Employee assessments can expose those executives who merely pay lip service to ethics and legal compliance by establishing the required code of conduct or following the technical wording of the accounting rules, while sidestepping the purposes and principles of those very same ethics codes and accounting requirements.

An employee assessment of management behavior can also reveal the tendency of management to override the policies and procedures that they declare have been established and implemented at the company. Executives who tout their company's effective internal control system, but then are discovered to have been committing financial accounting frauds or unjustly enriching themselves, are likely to have been overriding the company's policies, procedures, and programs. ${ }^{186}$ These are the business leaders who establish the required structural mechanisms, such as policies against conflict-of-interest transactions, but then override these same conflicts policies when it comes to their own conduct. ${ }^{187}$

Internal control activities, such as segregation of duties and authorization policies, cannot in themselves curb management misbehavior because executives can simply override these controls. ${ }^{188}$ Executives can initiate conflict-of-interest transactions, direct how those transactions will be accounted on the company's books, and then determine the extent and details of public disclosure of those transactions. Employees who have the opportunity to work with executives on a routine basis can expose senior management's ethics and integrity by revealing whether the executives apply the internal policies and procedures, as well as external laws and requirements, equally to all

186. See ASS'N OF CERTIFIED FRAUd EXAMINERS, supra note 166, at iv ("More effective types of internal controls are needed to detect fraud, especially larger frauds that may involve senior personnel overriding or circumventing traditional internal controls.").

187. See KPMG FORENSIC, supra note 102, at 5-6 (reporting that misconduct particularly relevant at the management level includes abusing or misappropriating corporate assets, engaging in conflict-of-interest transactions, and falsifying financial records, and attributing such misconduct to pressure to meet business targets and override of company policies).

188. See ADVISORY COMMITTEE REPORT, supra note 34, at 37. 
corporate employees, or whether the executives instead carve out generous exceptions when it comes to applying the policies and requirements to their own behavior.

Conducting employee assessments and reporting the results of organizational integrity can create reputational value. ${ }^{189}$ Executives are motivated by reputational value, especially when that reputation reflects personal attributes such as ethics and integrity. ${ }^{190}$ Reporting a weakness in the company's accounting control mechanisms does not call into question the personal characteristics of the executives, whereas reporting a weak review of organizational ethics brings to the forefront the executive's style of leadership and personal commitment to business integrity. ${ }^{191}$ The employee assessment, in its role as a certification of the integrity of the organization, can motivate a business to focus on ensuring that no ethical weakness within its executive rank will taint the reputation of the company as a whole. ${ }^{192}$ Reporting results of the employee assessment provides incentive for executives to focus on enhancing reputational value through ethical behavior in everyday business conduct.

Business leaders can restore the investor trust lost through business scandals of the past years by placing ethics at the forefront of how they make decisions and conduct business. By demonstrating allegiance to high business standards through actual decisions and conduct, executives communicate their integrity to internal employees who will then communicate the company's integrity to the public. Conducting and reporting employee assessments of organizational integrity will produce greater corporate transparency. That transparency may, in turn, engender social pressures and personal incentives to incorporate ethical considerations into the blinding competition for corporate profits or the personal quest for financial rewards. Disclosure of the company's ethical climate is likely to curb management abuses, whether illegal or

189. See BUSINESS ETHICS SURVEY, supra note 137, at 39 (noting that paying more attention to warnings from internal whistleblowers can reduce unethical conduct and financial losses while protecting corporate reputation).

190. See Timberly Ross, Buffett Memos Preach Ethics, ST. PAul PiOnEer Press, Oct. 11, 2006, at 3C (reporting Warren Buffett's reminder to top executives at his company, Berkshire Hathaway, and other corporate executives that " [y] can lose a reputation that took 37 years to build in 37 seconds.' . . . 'And it might take more than 37 years to build it back."').

191. See Treviño, supra note 141, at 1208 (noting that the image of the organization is linked more closely to the chief executive officer's personal identity than to other employees' identities).

192. See Ross, supra note 190 (reporting Warren Buffett's advice to the executives of his company against improper behavior and his warning that the company's "reputation is in your hands"). 
merely unethical, as business leaders are motivated to cultivate and preserve their reputation for high business ethics.

Finally, reporting on management's behavior through ethical dimensions could lead to different corporate and societal perceptions about the contribution of ethics to corporate performance. An employee assessment of management's behavior is an effective evaluation of the integrity of an organization because it captures, beyond the written internal accounting controls, the behavior executives exhibit and the ethical principles they apply in operating the business organization. Information on senior management's behavior and ethics can convey to internal and external constituents the organization's actual commitment to, and application of, responsible business practices. This information is important to investors, customers, and employees. ${ }^{193}$ Also, as past research has shown, companies demonstrating high standards of ethical conduct produce higher investment results over the long term. ${ }^{194}$ Thus, information that signals a company's high ethics can help the organization attract and retain investors, employees, and customers who are interested in affiliating themselves with a business that adheres to high standards of corporate conduct.

\section{CONCLUSION}

The curse of SOX 404 is that its implementation, in terms of time expended, financial resources diverted, and opportunities lost, has resulted in meager benefits. Conducting and reporting employee assessments of organizational integrity provides a practical, cost-efficient strategy to bring to light, and potentially curb, abuses of managerial power. Internal employees, who are exposed to senior management's decision-making and behavioral manifestations on a routine basis, have the opportunity and ability to communicate that information to external stakeholders who desire more knowledge of the organization's integrity.

193. See supra Part V.C.

194. See Soc. INV. ForuM, supra note 153, at 14 (noting that research has found significant correlation between social performance and financial performance); WATSON WYATT WORLDWIDE, WORKUSA 2002: WeATHERING THE STORM: A STUDY OF EMPLOYEE ATTITUDES AND OPINIONS 2 3 (2002) (finding that appreciation in stock price over three years plus dividends is three times higher at companies where employees have high trust in senior management than at companies with low trust levels); News Release, Rand Corporation, Rand and LRN Establish Alliance to Create Center for Corporate Ethics, Law and Governance (Sept. 7, 2004), http://www.rand.org/news/ press.04/09.07b.html (last visited Sept. 19, 2007) (““[T] here is growing evidence that now more than ever companies committed to the highest standards of conduct and ethics produce superior results and investment performance over the long term." (quoting Dov Seidman, chairman and CEO of LRN)). 
Employee assessments of company control environments will identify companies and executives who pay lip service to ethics and use control activities such as codes of conduct and training programs as window dressing, and benefit companies that back up their words with actions.

As the regulators have heard from a Commission advisory committee, continuing on the current course of interpreting and implementing SOX 404 to require management to assess and report on internal control activities will not make SOX 404 more effective at improving financial reporting or organizational integrity, and time will not eliminate the financial and opportunity costs of compliance. ${ }^{195}$ Instead of living with the curse of SOX for the eighty-plus years that it took to lift the curses that plagued the Red Sox and the White Sox baseball teams for their scandals, the burdens arising from requiring management assessments and reporting on internal control activities can be lifted in short order by conducting and reporting employee assessments of internal control environments and management ethics.

195. See AdVISORY COMMITTEe REPORT, supra note 34, at 125. 